\title{
SARS-CoV-2: is there neuroinvasion?
}

\author{
Conor McQuaid, Molly Brady and Rashid Deane* (1)
}

\begin{abstract}
Background: SARS-CoV-2, a coronavirus (CoV), is known to cause acute respiratory distress syndrome, and a number of non-respiratory complications, particularly in older male patients with prior health conditions, such as obesity, diabetes and hypertension. These prior health conditions are associated with vascular dysfunction, and the CoV disease 2019 (COVID-19) complications include multiorgan failure and neurological problems. While the main route of entry into the body is inhalation, this virus has been found in many tissues, including the choroid plexus and meningeal vessels, and in neurons and CSF.

Main body: We reviewed SARS-CoV-2/COVID-19, ACE2 distribution and beneficial effects, the CNS vascular barriers, possible mechanisms by which the virus enters the brain, outlined prior health conditions (obesity, hypertension and diabetes), neurological COVID-19 manifestation and the aging cerebrovascualture. The overall aim is to provide the general reader with a breadth of information on this type of virus and the wide distribution of its main receptor so as to better understand the significance of neurological complications, uniqueness of the brain, and the pre-existing medical conditions that affect brain. The main issue is that there is no sound evidence for large flux of SARS-CoV-2 into brain, at present, compared to its invasion of the inhalation pathways.

Conclusions: While SARS-CoV-2 is detected in brains from severely infected patients, it is unclear on how it gets there. There is no sound evidence of SARS-CoV-2 flux into brain to significantly contribute to the overall outcomes once the respiratory system is invaded by the virus. The consensus, based on the normal route of infection and presence of SARS-CoV-2 in severely infected patients, is that the olfactory mucosa is a possible route into brain. Studies are needed to demonstrate flux of SARS-CoV-2 into brain, and its replication in the parenchyma to demonstrate neuroinvasion. It is possible that the neurological manifestations of COVID-19 are a consequence of mainly cardio-respiratory distress and multiorgan failure. Understanding potential SARS-CoV-2 neuroinvasion pathways could help to better define the non-respiratory neurological manifestation of COVID-19.
\end{abstract}

Keywords: Blood-brain barrier (BBB), Cerebrospinal fluid (CSF), Choroid plexus, COVID-19, Aging, Obesity, Hypertension, Diabetes, ACE2, MMP9

\section{Background}

In late 2019, an outbreak of a new coronavirus $(\mathrm{CoV})$ was reported, which quickly became a pandemic [1]. This new $\mathrm{CoV}$ virus is called SARS-CoV-2 and causes the coronavirus disease, COVID-19 [2]. In the healthiest people, the majority of COVID-19 infections are asymptomatic, mild or moderate, who recovers after the infectious period,

\footnotetext{
*Correspondence: Rashid_Deane@urmc.Rochester.edu Department of Neuroscience, University of Rochester, URMC, 601 Elmwood Avenue, Rochester, NY 14642, USA
}

but in some cases, it can be life-threatening or debilitating. There are also concerns for those patients with some persistence symptoms after the usual infectious period (post-COVID-19 syndrome called 'long-haulers') [3-6]. While this virus infects people of all ages, most of those with a greater risk of requiring intense care and of dying from the infection are older individuals, and in particular men with pre-existing health conditions, such as respiratory diseases, obesity, hypertension, cardiovascular disease (CVD), and diabetes [7, 8]. Indeed, over $95 \%$ of the deaths from those infected were of patients $>60$ years old original author(s) and the source, provide a link to the Creative Commons licence, and indicate if changes were made. The images or other third party material in this article are included in the article's Creative Commons licence, unless indicated otherwise in a credit line to the material. If material is not included in the article's Creative Commons licence and your intended use is not permitted by statutory regulation or exceeds the permitted use, you will need to obtain permission directly from the copyright holder. To view a copy of this licence, visit http://creativecommons.org/licenses/by/4.0/. The Creative Commons Public Domain Dedication waiver (http://creativeco $\mathrm{mmons}$.org/publicdomain/zero/1.0/) applies to the data made available in this article, unless otherwise stated in a credit line to the data. 
and mostly men with comorbidities [7]. Also, post-infection hyperinflammatory diseases and multi-organ failure have been described as additional features of COVID-19. Thus, elderly individuals and those with co-morbidities are significant risk factors for developing severe COVID19 symptoms [9]. Obesity, diabetes, hypertension and aging are also risk factors for systemic vascular dysfunction [10].

This novel $\mathrm{CoV}$ is more contagious than the previous major $\mathrm{CoV}$ outbreaks, which caused severe acute respiratory syndrome (SARS) by SARS-CoV (SARS-CoV-1) in 2002 and Middle East Respiratory Syndrome by MERS$\mathrm{CoV}$ in 2012 [11]. The clinical manifestations of these infections are similar, since SARS-CoV-2, SARS-CoV and MERS-CoV share a high homology in their amino acids sequence [12]. Some symptoms of COVID-19 are similar to SARS, such as fever, cough, fatigue and body aches, which can include pneumonia and dyspnoea in severe cases [12]. Compared to SARS-CoV and MERS$\mathrm{CoV}, \mathrm{SARS}-\mathrm{CoV}-2$ have a lower case-fatality rate, but spreads more efficiently [13]. While the worldwide death rate of SARS-CoV and MERS-CoV were $~ 10 \%$ and $~ 36 \%$ of those infected, respectively, with a progressive rapid increase in testing, the current estimated death rate from SARS-CoV-2 is $<0.5 \%[14,15]$.

While acute respiratory distress syndrome (ARDS) is mainly associated with SARS, increasing clinical evidence of non-respiratory symptoms, include anosmia (smell dysfunction), dysgeusia (taste dysfunction), multisystem inflammation, vascular inflammation and neurological symptoms, have also been associated with COVID-19. Clinical evidence shows that SARS-CoV-2 causes a Kawasaki-like syndrome in younger patients; with wide spread vascular inflammation [8], which may indicate it is also a vascular disease. Kawasaki disease, acute febrile illness, is seen in young children. The main features are fever, rash, swelling of the hands and feet, redness of the eyes, irritation and inflammation [16]. There are reports of children and young adults with COVID-19 having varied manifestations of hyperinflammatory states and/or Kawasaki-like disease. Consequently, these hyperinflammatory features involving multiply organs are described as multisystem inflammatory syndrome (MIS). While most COVID-19 cases $(>90 \%)$ in children are described as asymptomatic, mild or moderate infections, the long-term effects of this on the brain is unclear $[16,17]$.

The cerebrovasculature is susceptible to hypoxia; therefore cardio-respiratory failure and systemic inflammation can potentially damage the vasculature, leading to death. There is an urgent need to understand the pathogenic mechanisms of this virus so as to find solutions that will effectively diagnose, treat and prevent this disease, and the inevitable similar outbreaks, especially with the expected evolution of variants associated with these viruses. Thus, a better understanding on how SARS$\mathrm{CoV}-2$ affects the systems, the cerebrovasculature and whether there is neuroinvasion would have additional benefits in improving outcomes for infected susceptible patients in the short- and long-term, such as the so called 'long-haulers'. The aim of the review is to provide the general readership with the breadth of information on the virus, the distribution of its main host cell receptor, the brain vascular barriers, and the pre-existing medical conditions that affect brain. The main issue is that there is no sound evidence for large flux of SARS-CoV-2 into brain, at present, to support a brain invasion compared to the lungs and respiratory pathways.

\section{SARS-CoV-2 and COVID-19}

CoVs are a diverse family of viruses with a large host range, including humans, and are primarily associated with mild respiratory infections of the upper respiratory tract $[9,18]$. Bats appear to have a large reservoir and diversity of CoVs (including HCoV-NL63, HCoV-2295, SARS-CoV, MERS-CoV and SARS-CoV-2) [18]. The current consensus is that SARS-CoV-2 likely originated from bats and was transmitted to humans via an intermediate host, possibly pangolins $[19,20]$. Further work is needed to confirm this.

SARS-CoV-2, about $100 \mathrm{~nm}$ in diameter, is made up of a lipid membrane viral envelop that encloses the nucleocapsid, which is the genetic content of the virus that interacts with the host genetic material [21]. The lipid plasma membrane has structural proteins, namely the spike protein $(\mathrm{SP})$, membrane protein, small membrane protein and hemagglutinin-esterase [21]. SP promotes attachment and facilitates entry into host cells by binding $(\mathrm{kd} \sim 5 \mathrm{pM})$ to the extracellular peptidase domain on angiotensin converting enzyme (ACE) 2 receptors (ACE2) on the plasma membrane [22]. TMPRESS 2 (transmembrane protease, serine 2) on the host cells cleaves the SP to facilitate viral entry [23]. SP may also interact with CD147 (EMMPRIN (extracellular matrix metalloprotease inducer)) in its invasion and dissemination processes [24]. The role of CD147 on SARS-CoV-2 spike protein-mediated disruption of cardiac pericyteendothelial cells has been reported [25]. Also, CoV attachment to oligosaccharide receptors via sialic acid contributes to viral entry into host cells [26]. Glycoprotein containing sialic acid and $\mathrm{N}$-acetylglucosamine was shown to mediate recombinant spike protein uptake into the murine brain [27]. However, it is unclear if CD147 or sialic acid mediates SARS-CoV-2 entry into host cells.

Thus, due to the similarity between CoVs, there are likely multiple interaction sites between SARS-CoV-2 
and host cells, which may lead to the diverse symptoms of COVID-19, and also potential therapeutic targets.

\section{SARS-CoV-2 variants}

While viruses mutate as they replicate and spread, the frequency of mutation and the characteristics of the variants vary. Mutations can be favorable, neutral or deleterious by altering the virulence and transmissibility, or produce no change in viral behavior. Since variants may affect the efficacy of vaccines, diagnostic methods, and could overwhelm the healthcare system, there is increased genomic surveillance. This has detected a number of SARS-CoV-2 variants worldwide, and there are emerging data on the characteristics of some these variants (Table 1).

The UK (B.1.17), South Africa (B.1.351) and Brazil (P.1) variants are spreading in many counties, and others that will become more widespread. While these variants harbor a number of mutations, there are a few key mutation sites that may influence viral behavior. N501Y, an asparagine to tyrosine amino acid substitution at position 501 in the viral SP, is present in all three variants, and experimental data suggest this mutation increases its affinity for human ACE2 receptor [28]. A study in mice found that this mutation increases infectivity and sickness [28]. D619G is a mutation in the SP that is also shared by all 3 variants. In vitro data show that D619G increases infectivity by enhancing the SP/ACE2 receptor binding and fusion [29-31]. In animal models, D619G mutation enhanced replication rate in the upper respiratory tract and transmission [29, 32, 33]. P681H (found in the B.1.1.7 variant) is a mutation in the SP near the SP (S1/S2) furin cleavage site, but the biological relevance is unclear [34, 35]. E484K (found in P.1, B.1.351, and B.1.525-526 variants), a mutation in the receptor binding domain of the SP, reduces the ability of antibodies, collected from people who recovered from COVID-19, to neutralize the virus. This raise concerns that these mutations could pose a greater risk to the population because it may be better at reinfecting people and some vaccines might not be as efficacious [36].

The Denmark mink variant is consisted of a cluster of 5 mutations (69/70 deletion, Y453F, I692V, M1229I, S1147L), but the implications of these mutations are not well understood. However, preliminary findings indicate that this particular mink-associated variant, identified in both minks and human cases, has moderately decreased sensitivity to neutralizing antibodies [37-40].The adaptation of SARS-CoV-2 to mink, and the fear of the possibility that mink farms could be an animal reservoir for this viral variant led to the large-scale culling of minks on farms, and increased surveillance [38, 39].

A recent analysis suggests the presence of mutations in the USA from 45,494 complete SARS-CoV-2 genome sequence of COVID-19 patients [41]. Mutations P504L, Y541C, and L84S tend to fade out, while T85I, P323L, D614G, Q57H, L84S, R203K, R203K, and G204R may become more infectious. Interestingly, the Wang et al.

Table 1 Known SARS-CoV-2 variants

\begin{tabular}{|c|c|c|c|c|c|c|c|}
\hline $\begin{array}{l}\text { Colloquially } \\
\text { name }\end{array}$ & $\begin{array}{l}\text { Scientific name: } \\
\text { Pangolin } \\
\text { Nextstrain }\end{array}$ & Defined by & $\begin{array}{l}\text { Important } \\
\text { mutations }\end{array}$ & $\begin{array}{l}\text { Countries } \\
\text { reported (first } \\
\text { detected) }\end{array}$ & $\begin{array}{l}\text { Increased } \\
\text { transmissibility }\end{array}$ & $\begin{array}{l}\text { Increased } \\
\text { COVID-19 } \\
\text { mortality or } \\
\text { severity }\end{array}$ & Effect on vaccines \\
\hline UK variant & $\begin{array}{l}\text { B.1.1.7 } \\
\text { 20I/501Y.V1 } \\
\text { VUI-202012/01 }\end{array}$ & 17 SNPs & $\begin{array}{l}-\mathrm{N} 501 \mathrm{Y} \\
-69 / 70 \text { deletion } \\
-\mathrm{P} 681 \mathrm{H} \\
-\mathrm{D} 619 \mathrm{G}\end{array}$ & $\begin{array}{l}75 \text { (34) } \\
\text { (United King- } \\
\quad \text { dom) }\end{array}$ & $\begin{array}{l}\text { Yes }(\sim 50-70 \%) \\
{[34,35} \\
263-266]\end{array}$ & $\begin{array}{l}\text { Possibly [267, } \\
268]\end{array}$ & $\begin{array}{l}\text { Oxford/AstraZen- } \\
\text { eca still effective } \\
\text { [269] }\end{array}$ \\
\hline $\begin{array}{l}\text { South African } \\
\text { variant }\end{array}$ & $\begin{array}{l}\text { B.1.351 } \\
20 H / 501 Y . V 2\end{array}$ & 9 SNPS & $\begin{array}{l}-\mathrm{N} 501 \mathrm{Y} \\
-\mathrm{K} 417 \mathrm{~N} \\
-\mathrm{E} 484 \mathrm{~K} \\
-\mathrm{D} 619 \mathrm{G}\end{array}$ & $\begin{array}{l}32(34) \\
\text { (South Africa) }\end{array}$ & $\begin{array}{l}\text { Yes }(\sim 50 \%) \\
{[34,35,270]}\end{array}$ & Possibly [270] & $\begin{array}{l}\text { Moderna may be } \\
\text { less effective } \\
{[271,272]}\end{array}$ \\
\hline Brazil variant & $\begin{array}{l}\text { P.1 } \\
\text { B.1.1.28 } \\
20 \mathrm{~J} / 501 \mathrm{Y} . \mathrm{V} 3\end{array}$ & 19 SNPS & $\begin{array}{l}-\mathrm{N} 501 \mathrm{Y} \\
-\mathrm{K} 417 \mathrm{~T} \\
-\mathrm{E} 484 \mathrm{~K} \\
-\mathrm{D} 619 \mathrm{G}\end{array}$ & $\begin{array}{l}12(34) \\
\text { (Brazil) }\end{array}$ & Yes [35] & N/A & N/A \\
\hline New York & $\begin{array}{l}\text { B.1.525-B.1.526 } \\
20 C\end{array}$ & 13 SNPS & $\begin{array}{l}-\mathrm{D} 614 \mathrm{G} \\
-\mathrm{E} 484 \mathrm{~K} \\
-\mathrm{Q} 677 \mathrm{H} \\
-\mathrm{F} 888 \mathrm{~L}\end{array}$ & $\begin{array}{l}30 \\
\text { (Multiple) }\end{array}$ & yes & N/A & $\begin{array}{l}\text { Reduction in } \\
\text { neutralization } \\
\text { by monoclonal } \\
\text { antibodies }\end{array}$ \\
\hline California & $\begin{array}{l}\text { B.1.427-B.1.429 } \\
20 C / S: 452 R\end{array}$ & 10 SNPS & $\begin{array}{l}-L 452 R \\
-D 624 G \\
-N 501 Y\end{array}$ & $\mathrm{~N} / \mathrm{A}$ & Yes ( 20\%) & N/A & $\begin{array}{l}\text { Reduction in } \\
\text { neutralization } \\
\text { by monoclonal } \\
\text { antibodies }\end{array}$ \\
\hline
\end{tabular}


paper also shows that mutant S24L shows a female-dominated pattern, and a more active immune systems than those of males in responding to SARS-CoV-2. Mutations on the spike protein, D614G and S24L are likely more infectious.

How these variants alter the effects of SARS-CoV-2 on the neurovasculature and neuroinvasion are unclear. Some of these mutations alter the SP, and increased the affinity for the ACE2 receptor. However, it has been demonstrated, albeit with a different receptor, that high affinity actually decreased the amount of transcytosis across the endothelium, as the cargo ended up in the lysosomal pathway [42]. If there is a non-receptor mediated entry pathway into brain that is not specific then the variants should not affect entry, but may alter its effects on brain.

\section{Evolution of COVID-19 symptoms: outlined}

The evolving events that lead to the development of COVID-19 symptoms are shown in Fig. 1. SARS-CoV-2 enters the body mainly as droplets during inhalation, and infiltrates the nasal and buccal cavities to gain access to the nasal mucosa and the respiratory tract, which may explain the dysgeusia and anosmia effects [43]. The virus infects the epithelium that lines the surfaces of the trachea, bronchi, bronchioles and alveoli.

The innate immune system through pathogen recognition receptors (PRRs), such as the Toll-like receptors (TLRs) and the RNA helicases, detect pathogen-associated molecular patterns (PAMPs) on viruses and trigger an antiviral response. TLRs are expressed in dendritic cells (DCs) and macrophages but can be found in nearly all human cells.

E.g., brain endothelial cells express TLR4 that can elicit proinflammatory response [44]. The TLR2/4 is expressed in the choroid plexus and circumventricular organs [45]. Equine encephalitis virus interacts with TLR4 and disrupt $\mathrm{BBB}$ permeability [46]. It is tempting to think that SARS-CoV-2 can also interact with these receptors. Depending on the viral load, this system is effective in eliminating the virus with minimal local and systemic inflammation (for details see, e.g., [47-54]). Thus, an effective and robust immune response can alter the outcomes of the COVID-19 infection, and contribute to a better one, such as those seen for the asymptomatic, mild and moderate cases [55].

The innate immune system plays a pivotal role by secreting mucus along the respiratory tract, which stimulates coughing and the action of cilia to remove it. The alveolar epithelium lacks mucocilliary properties but has resident granulocytes and macrophage that interacts with the virus to raise an alarm; the inflammatory response, which mobilizes and direct the body's defense mechanisms to the sites of viral invasion (the lungs). Cytokines (e.g., IL-1, IL-6 and TNF- $\alpha$ ) are released to stimulate the immune response, mobilize the defense mechanisms, and increase body temperature by altering the set-point in the hypothalamus [56-58]. Neutrophiles are the first immune cells to be directed to the site of infection and play a crucial role in defense process, such as phagocytosis and neutrophil extracellular traps [47, 48, 51, 59-62]. Additionally, macrophages can phagocytose SARS-CoV-2 [63, 64]. Anti-viral cytokine (interferon (IFN)) is also secreted $[63,64]$. T-cells and B-cells are also stimulated, and later B-cells produce antibodies specific to the viral antigens, which can be used as evidence of SARS-CoV-2 infection, and as a possible therapy.

In response to the infection, other cells, such as mast cells, in the lungs are stimulated to release histamine, which contributes to the increased blood flow and capillary permeability leading to fluid accumulation [65]. As this increase, the alveolar can no longer perform the essential function of blood oxygenation and removal of carbon dioxide. Consequently, this decreases arterial blood $\mathrm{pO}_{2}$ and increased $\mathrm{pCO}_{2}$, which stimulates chemoreceptors in the carotid bodies, at the bifurcation of the common carotid artery, and in the central nervous system (CNS). This attempts to increase blood oxygenation by increasing ventilation and cardiac output, but due to cardio-respiratory failure, patients require a respirator to maintain this function.

\section{ACE2: a key player for SARS-CoV-2}

ACE2, a multifunctional nonocarboxypeptidase with one zinc-binding motif, plays a protective role by counteracting the effects of ACE (Fig. 2). It also hydrolyzes other peptides, such as apelin, an inotropic and cardioprotective agent [66], and kinins, which are vasoactive peptides [67]. In the intestine and kidney, ACE2 is involved in regulating amino acid transport[68]. ACE2 levels are reduced with aging, possibly due to increased activity of a disintegrin and metalloprotease17 (ADAM17) [69].

There are two forms of ACE2, membrane bound (mACE2) and the soluble circulating active extracellular domain (sACE2) [70]. During normal physiological function, and SARS-CoV-2 infection, CD147 and ADAM17 cleaves the extracellular domain of the mACE2 and release sACE2 into blood [71-76]. sACE2 levels are similar in children of both genders $<12$ years old, but in older adults this is increased greater in males than females [77]. Interaction of sACE2 with SARS-CoV-2 could act like a decoy receptor, which may attenuate SARS-CoV-2 interaction with mACE2. sACE2 may also distribute SARS-CoV-2 to all organs, including liver and kidneys, for, possibly, elimination. Soluble ACE2/SARS-CoV-2 binding domain or its analogous could be used to sequester blood 


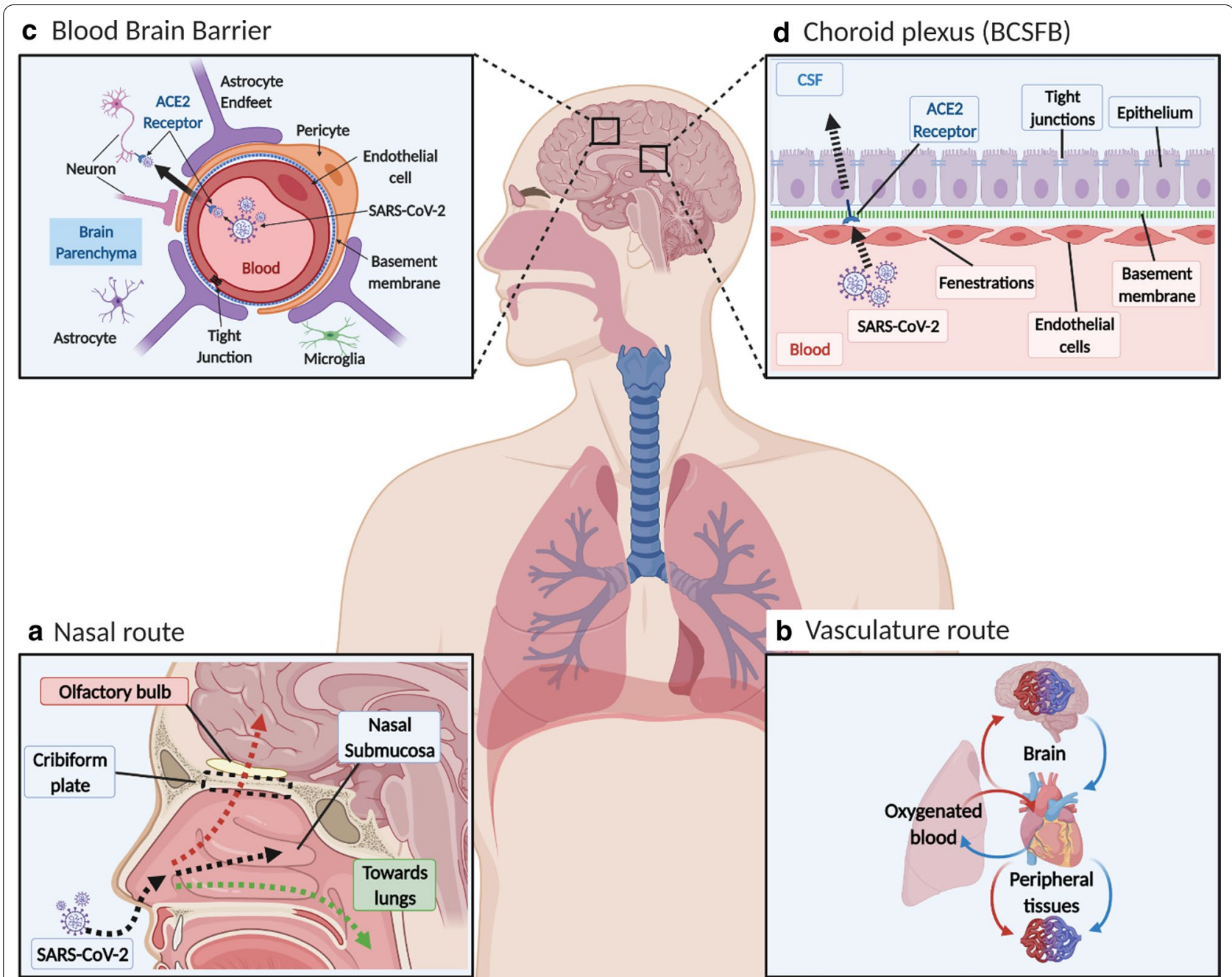

Fig. 1 SARS-CoV-2 distribution in blood and possible entry into brain across the CNS vascular barriers. a Nasal entry. SARS-CoV-2 enters the nasal cavity as droplets, and (1) enters the airways with the inspired air, (2) traffic into the nasal sub mucosa via the highly vasculature of the nose and enters the blood and/or lymphatics and (3) may get access to the olfactory nerves and thus olfactory bulb by going upstream, but to date there is no sound data to viral entry into brain. $\mathbf{b}$ Vasculature entry. After it enters the lungs it may cross the thin alveolar membrane and enters the blood to access all organs, including brain, but there is no evidence that ACE2 mediate viral entery into brain. c Blood brain barrier (BBB). This is a highly specialized structure at the interface between the blood and the brain. It is formed by tight junctions at the endothelial cells and forms part of a complex cellular structure known as the neurovascular unit (NVU). The NVU is the functional unit of the BBB and is composed of multiple cells including, pericytes, astrocytes, microglia and neurons interacting with the endothelial cell, as well as the basement membrane, which all can affect the barrier properties. ACE2 is expressed both on endothelial cell and pericytes as well as some neurons in the brain, but there is no evidence that ACE2 mediate viral entery into brain. $\mathbf{d}$ Choroid plexus. This is at the interface between the blood and the CSF, known as the blood CSF barrier (BCSFB). The endothelial cells of the choroid plexus are leakier than in the BBB, with gaps known as fenestrations. This allows for easier movement from the blood, but the epithelium cells at the apical side are more tightly knitted together (tight junction at the apex of the epithelium), and prevent entry into CSF [261, 262], as effective as the cerebral capillaries. The choroid plexus epithelium expresses ACE2 and this acts as a possible way for SARS-CoV-2 entry into CSF and then brain parenchyma, but there is no sound evidence for this

SARS-CoV-2 and to minimize its binding to mACE2. Since SARS-CoV-2 causes the loss of mACE2 it may increase angiotensin II effects. Thus, sACE2 levels could modulate COVID-19 severity, and also contributes to the benefits of convalescence plasma therapy.

\section{ACE2 main beneficial functions}

ACE2's main function is to regulate arterial blood pressure (BP) by changing total peripheral resistance to blood flow and fluid balance [14, 23, 78]. This is part of the well-known renin-angiotensin system (RAS) (Fig. 2). 


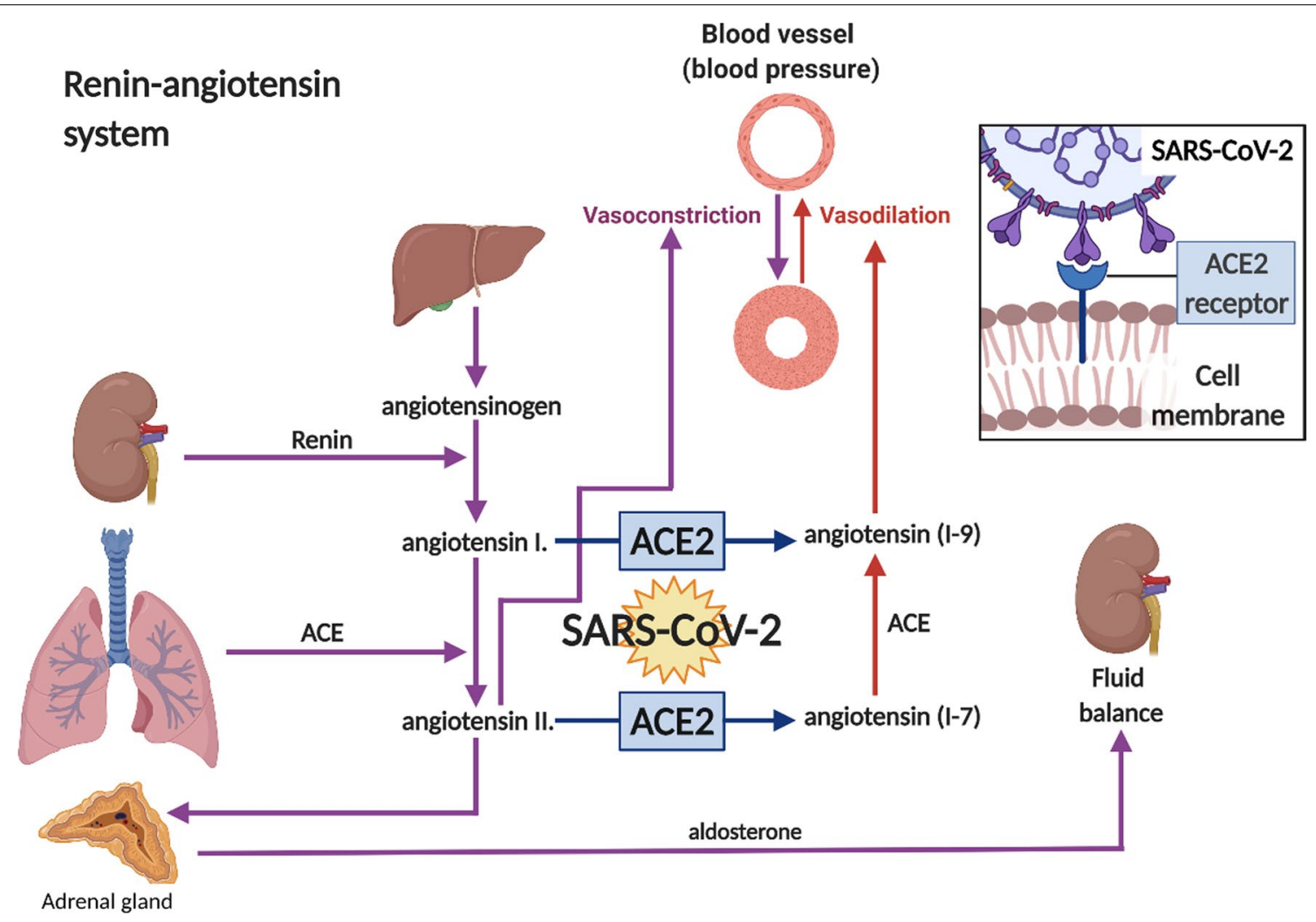

Fig. 2 Renin-angiotensin system. ACE2 is exploited by SARS-CoV-2 when infecting host cells. Renin, secreted from the kidneys in response to changes in blood flow and pressure, catalyses the conversion of the plasma protein called angiotensinogen into angiotensin I, angiotensin converting enzyme (ACE) converts angiotensin I into angiotensin II. Angiotensin II acts via receptors in the adrenal gland, causing the secretion of aldosterone, which causes the kidney to reabsorb salt and water. Angiotensin II is a powerful vasoconstrictor. ACE2 activity alters the ratio between angiotensin I to angiotensin (1-9) and angiotensin II to angiotensin (1-7). Angiotensin (1-7) can be converted to angiotensin (1-9) by ACE, and both have been shown to cause vasodilation. It has been shown that SARS-CoV-2 spike protein binds to the ACE2 receptor and shift the balance towards angiotensin II

While the components of RAS pathways are present in the brain and the periphery, they do not directly interact, but cooperate via centers in the brain to maintain blood pressure and plasma volume [14]. RAS components are widely expressed in the brain, especially in regions that regulate the cardiovascular system (CVS) and osmoregulation, including the hypothalamic paraventricular nuclei, supraoptic nuclei, ventrolateral medulla and the solitary nucleus [79]. Angiotensin-11, generated via ACE, increases BP by increasing vasoconstriction of arterioles and fluid retention by increasing the secretion of aldosterone, in addition to inflammation, oxidative stress and injury. Degradation of angiotensin- 1 and angiotensin-11 by ACE2 generates angiotensin (1-7) and angiotensin (1-9), which reduce BP, by increasing vasodilation and reducing plasma volume, inflammation, oxidative stress and injury [80]. For example, the phenotype of $\mathrm{ACE} 2^{-/-}$mice includes hypertension, behavioural dysfunction, impaired serotonin synthesis and neurogenesis [81]. In addition, ACE2 polymorphism is associated with essential hypertension [82]. Increased levels of brain ACE2 are associated with delay in cognitive decline [83]. Thus, ACE and ACE2 have a synergistic effect (Fig. 2). Inactivation of ACE2 as seen with SARS-CoV-2 infection could exacerbate angiotensin- 11 adverse effects, such as inflammation, and perhaps, contribute to COVID-19 adverse effects. Reduced ACE2 levels are associated with sperm-related infertility [84], pulmonary hypertension [85], kidney disease [86] and acute lung injury [87, 88]. In contrast, estrogen is reported to increase ACE2 activity [89], and protects against CVD. Thus, ACE2 has a wide range of beneficial effects, but is not directly associated with initiation of inflammation.

\section{ACE2 expression}

ACE2 is ubiquitously expressed on the cell membrane in many tissues, including those of the respiratory and cardiovascular systems, gastrointestinal tract, testes, kidneys, choroid plexus, placenta and bladder [14, 23, 78]. It is expressed in the heart (myocytes), vascular 
endothelial cells, and vascular smooth muscles cells of arteries and venules [21]. ACE2 is highly expressed on type 1 and type 11 epithelial cells and bronchiolar epithelium [90, 91]. In addition, it is also expressed on the oral mucosa [92].

ACE2 protein and mRNA are expressed in rodent brains $[93,94]$. ACE2 mRNA is present in the cortex, striatum, hippocampus and brain stem [95]. It is expressed in cultured glial cells, although it is unclear if this occurs in non-cultured glial cells [96]. ACE2 is mainly expressed in the cytoplasm of neurons and in brain regions associated with regulation of the CVS, blood pressure (BP) and the autonomic nervous system [97]. More recently, it was reported that the brain endothelium expresses ACE2 as the protein [98] and as the RNA-seq [99]. ACE2 as well as other facilitators are present in arterial and venous endothelial cells and arterial smooth muscle cells [90]. The brain vascular endothelium shows a high expression of the SARS-CoV-2 protease cathepsin B (CTSB) but not for TMPRSS2. CTSB is expressed in veins and capillaries in brain vasculature [100]. ACE2 is highly expressed on pericytes [101]. The expression of ACE2 in cerebral endothelial cells is still obscure. It was suggested that ACE2 is present on human cerebral micro vessels using immunohistochemistry [98] and brain endothelial cells [90]. Confirmation of the vessel type and whether ACE2 is on cell membrane or intracellular are needed. In general, ACE2 has a protective role for many organs, but the significance of ACE2 role on the in vivo cerebral endothelium compared to that of peripheral organs in COVID-19 needs to be determined.

\section{ACE2/SARS-CoV-2}

ACE2 is the primary mechanism of SARS-CoV and SARS-CoV-2 entry into host cells [78]. Although SARS$\mathrm{CoV}-2$ is similar to beta Coves, the receptor binding site is more comparable to SARS-CoV, but binds to the host cell receptor with a higher affinity than that of SARS-CoV [102]. The wide expression of $\mathrm{mACE} 2$ receptor suggests that many systems will be affected by SARS-CoV-2. Thus, critical cases of COVID-19 infection commonly manifest as cardiopulmonary symptoms and in severe cases, advanced into multiorgan failure and sepsis, hypothesized to be as a result of a "cytokine storm". However, some cells without a detectable expression level of ACE2, such as hepatocytes have been shown to be infected by SARS [103]. The infectious agents of SARS and MERS were also reported in the CNS where the expression level of ACE2 or DDP4 (MERS binding receptor) is very low under normal conditions $[103,104]$. Thus, there are other mechanisms that may facilitate viral entry in these organs.

\section{CNS vascular barriers: restrict trafficking into and out of brain}

The CNS is unique in that it is enclosed within its vascular barriers, and has cerebrospinal fluid (CSF) continuously circulating within it. The brain has a high demand for oxygen and metabolites, and normally receives about $20 \%$ of the cardiac output [105], and as a result is more sensitive to hypoxic and ischemic conditions. The total length of the human brain microvasculature is approximately $600 \mathrm{~km}$ with a surface area of about $15-25 \mathrm{~m}^{2}$ $[106,107]$. It is estimated that each neuronal cell body is within $10-20 \mu \mathrm{m}$ from the nearest capillary, which allows for rapid diffusion of metabolites and nutrients [108]. The cerebrovasculature is an important metabolic regulator for the CNS [109].

\section{Vascular barriers}

The vascular barriers at the blood-brain interface (the blood brain barrier, BBB) and blood-CSF interface (blood CSF barrier; the choroid plexuses) restrict the free diffusion of polar molecules into and out of the brain, while essential metabolites are transported into brain and/or into CSF [105, 110-114]. The physical site of the BBB and blood CSF barrier is the tight junctions between endothelial cells and epithelial cells, respectively $[115,116]$, which restricts paracellular diffusion. The endothelium of the cerebrovasculature is at the interface between the blood and brain, but there are several cell types on the abluminal side of the endothelium. These include pericytes, astrocyte end-feet and microglia, which maintain and regulate the $\mathrm{BBB}$, and couples regional cerebral blood flow to meet metabolic demands [105]. Collectively these cell types make up the neurovascular unit (NVU) (Figs. 3, $4,5)$ The vascular barriers also contribute to reducing the traffic of leukocytes, and microorganisms, such as viruses, from entering the brain as these require specific receptors for attachment [117].

The ependymal layer, which is an epithelium that lines the floor of the ventricles at the interface of CSF and brain parenchyma, provide regional structural and functional specializations $[118,119]$. Unlike the modified ependymal cells that form the epithelial cells of the choroid plexus (tela choroidea), the epithelium between CSF and brain parenchyma constitutes a partial barrier, since most of these cells lack the tight junctional proteins. These ependymal epithelial cells are mainly joined with adherens and gap junctional proteins [120-124]. Thus, the barrier between the epithelial cells that separates brain parenchyma and CSF is not as effective as that at the blood-CSF interface [125, 126], and small watersoluble dyes, administered into CSF, is readily detected in brain [120, 122]. 


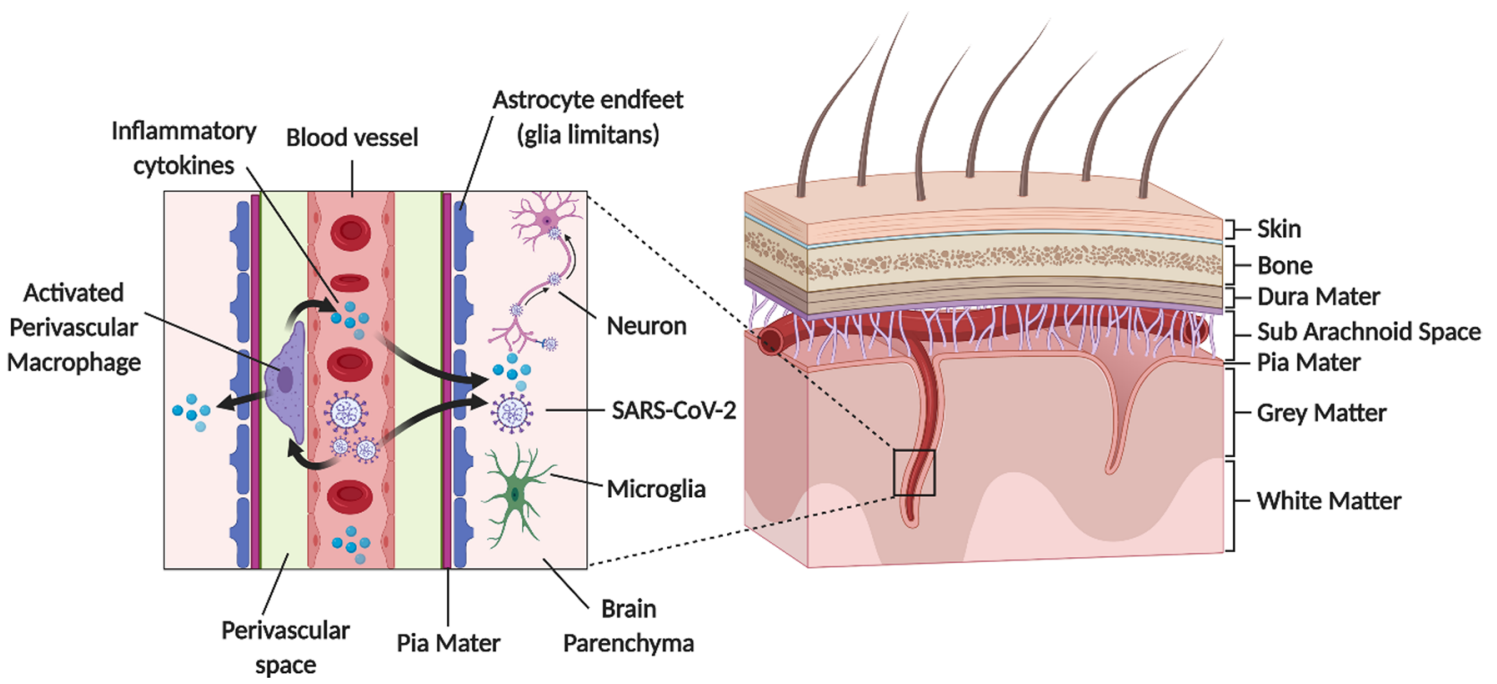

Fig. 3 Schematic diagram showing perivascular SARS-CoV-2 entry into brain. penetrating arterial vessel and a magnified region (boxed area) showing possible access site of the virus via the perivascular space. This could activate perivascular macrophage leading to neuroinflammation

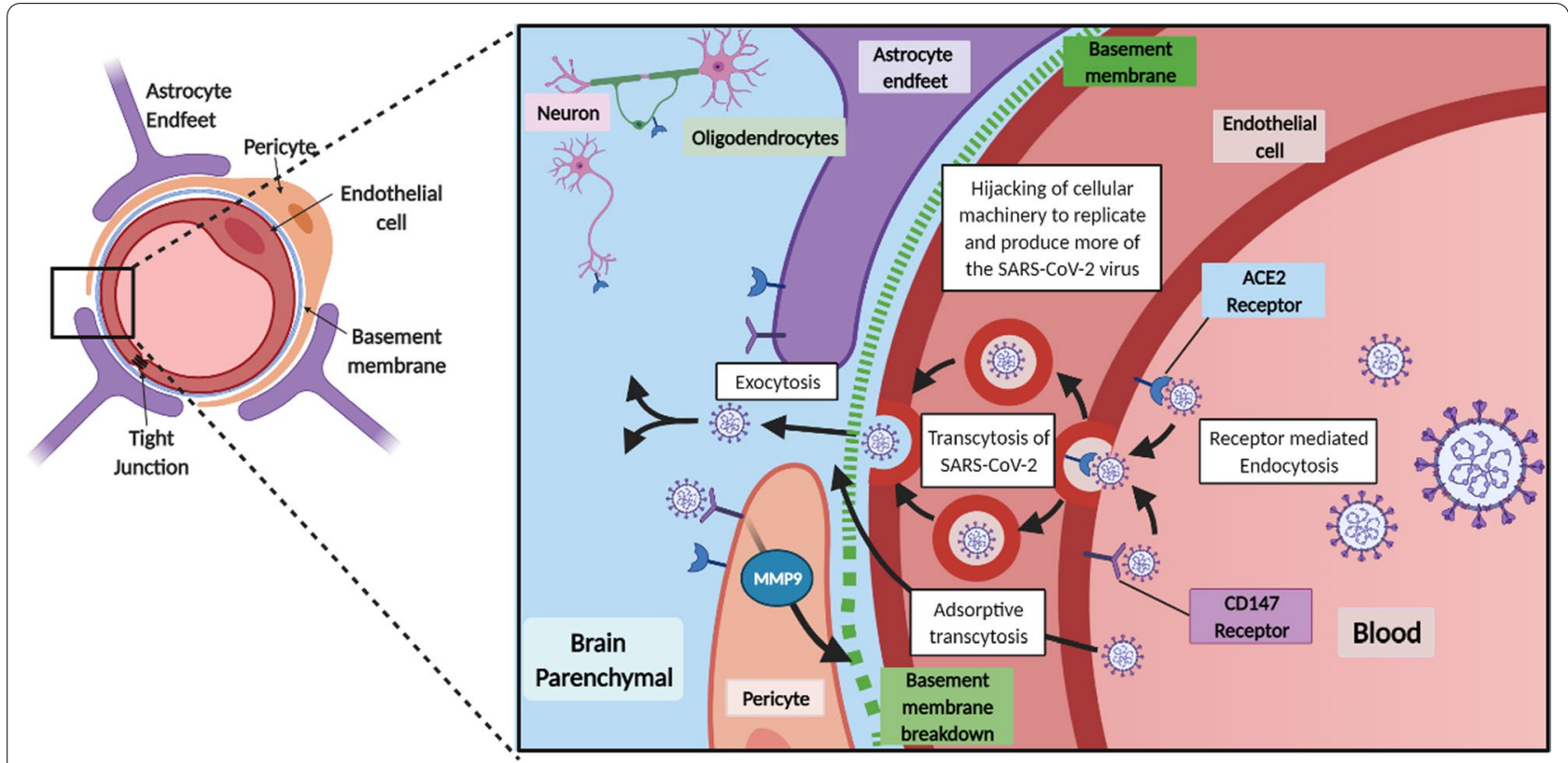

Fig. 4 SARS-CoV-2 interaction and transport across the BBB. Normal and infected neurovascular unit (NVU). A normal BBB restricts and controls the entry of substances in and out of the brain. Tight junctions between endothelial cells restrict the movement via the paracellular route for small molecules, like ions (e.g., potassium, sodium). Along with this tight barrier there is also low levels of pinocytosis, numerous transporters for select molecules, and efflux pumps to remove substances from the brain into the blood. In an infected/diseased BBB, there is the possibilities that tight junctions loosen, allowing larger molecules to pass via the paracellular route into the brain, decrease in efflux pumps and transporters as well as increased pinocytosis altering the balance across the barrier. Basement membrane breakdown on the abluminal surface can cause increase the barrier permeability. Viral infection can cause the release of cytokines, which can alter the integrity of the BBB and increase immune cell penetration into the brain

\section{CSF}

CSF is mainly produced within the cerebral ventricles by the choroid plexuses, and circulate from the lateral ventricles to the subarachnoid space, around the brain, spinal cord and within the spinal canal, before ultimately draining at multiple outflow sites into blood 


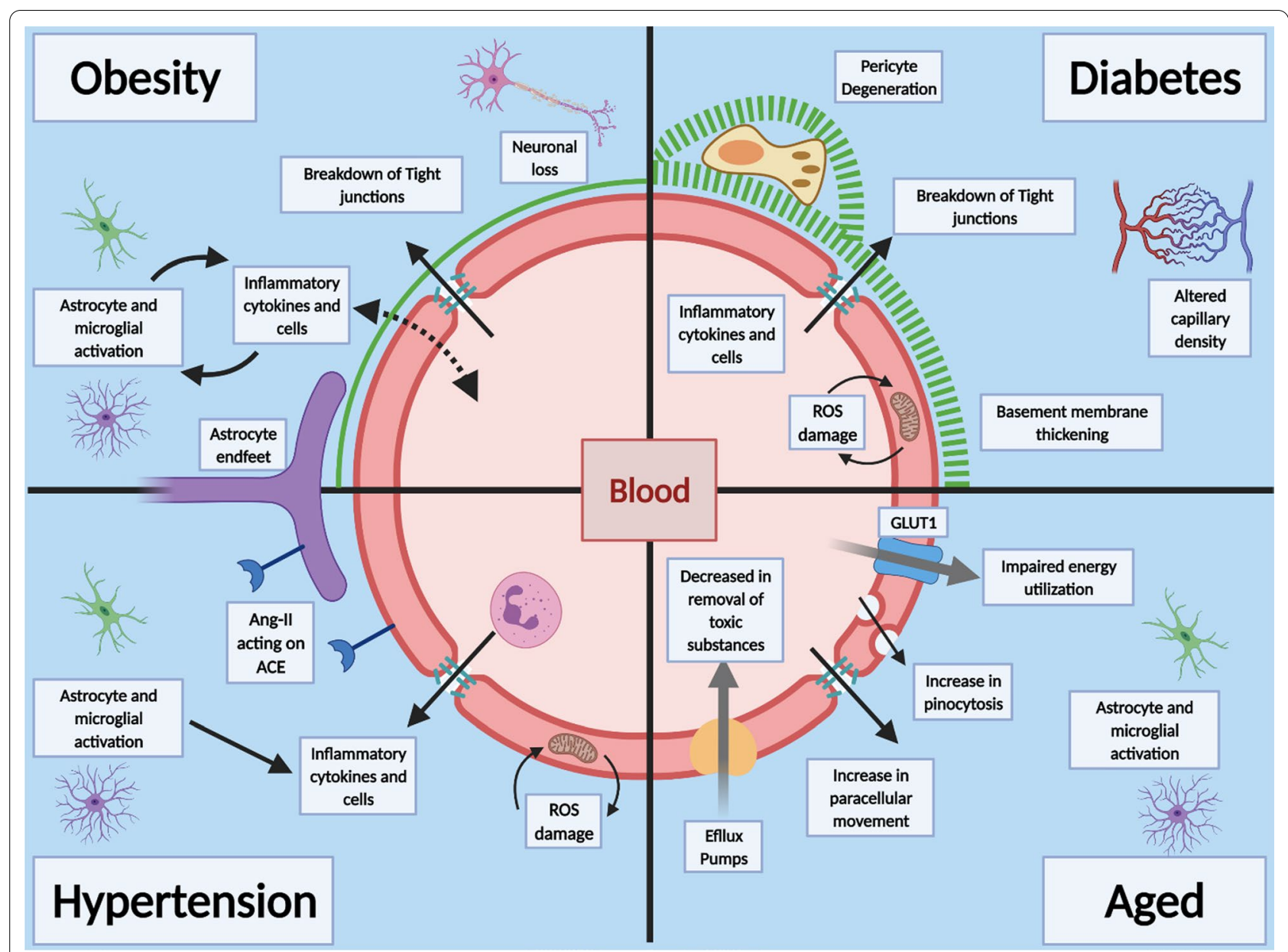

Fig. 5 Prior health conditions effects on the BBB. Obesity is linked to increase in inflammatory cytokines which can lead to activation of astrocytes and microglia and death of neuronal cells, leading to wide spread neuro-inflammation, tight junction breakdown and damage to the CNS.

Diabetes and hyperglycaemia cause pathological changes to the BBB, including increased capillary density, thickening of the basement membrane, breakdown of tight junctions and increase in paracellular diffusion. Pericytes are also shown to degenerate and aid in the decrease in barrier properties. Hypertension is linked to the RAS system and Ang-11 levels, increase in inflammatory cytokines and Reactive oxygen species (ROS) damage to endothelial cells and activation of microglia and astrocytes. Age has widespread effects on the BBB, decrease in barrier functions, decrease in efflux pumps and impaired energy utilization. There is also increased movement across the BBB by increase in paracellular movement, increase in pinocytosis leading to astrocytes and microglia activation

[127-129]. This is the third circulation or pseudo lymphatics of the brain since the brain parenchyma lacks lymphatic vessels [130-134]. A major CSF drainage pathway is via the olfactory bulb, across the cribriform plate and towards the cervical lymphatic nodes, and the spinal cord [135-138]. There is no significant flow of CSF from the subarachnoid space to the brain parenchyma, under near normal experimental conditions (e.g., [138]). The flowing CSF maintains intracranial pressure and contributes to the removal of metabolites $[127,139]$.

Some viruses, such as Zika, human immunodeficiency virus (HIV) and human polyomavirus, enter CSF via the choroid plexus [140-143]. SARS-CoV-2 interact with organoid human pluripotent stem cell of the choroid plexus [144]. However, it's unclear on whether SARSCoV-2 crosses the choroid plexus in humans to significantly contribute to neuroinvasion and inflammation. The virus RNA was detected in the CSF of a COVID-19 patient with meningitis [145]. In contrast, the SARSCoV-2 RNA was not detected in the nasopharyngeal swab but was detected in the CSF [146]. In addition, there are reports of the presence of SARS-CoV-2 in the CSF[147] and other reports showing that it is not in CSF $[12,148]$. While there are indications that the virus is present in the olfactory mucosa, using autopsy samples, it's still unclear if SARS-CoV-2 invades the human brain to contribute significantly to the disease outcomes. 
Leukocytes traffic across the NVU and choroid plexus to enter brain parenchyma. Although a robust immune response can be mounted in the CNS, this organ is normally immunologically quiescent [149]. The majority immune cells found in the CSF of healthy individuals are $\mathrm{T}$ cells that have entered the CNS through the BBB, choroid plexus and meninges. Intravenously administrated fluorescently labelled lymphocytes are detected in some of these regions, in mice [50, 54, 150-152]. Some viruses, such as Zika and influenza A, can enter brain associated with monocytes, which can be a repository of these viruses [153-155]; While SARS-CoV-2 activates systemic monocytes [156], there is no evidence that it is involved in SARS-CoV-2 traffic into brain.

\section{COVID-19 and neurological symptoms}

COVID-19 clinical signs are mainly associated with respiratory symptoms, but there is evidence that there are adverse neurological symptoms, including anosmia, dysgeusia, headaches, nausea and vomiting $[21,96]$. These symptoms may have short- and long-term adverse effects on infected people, especially those with pre-existing health conditions. Earlier observations of COVID-19 infection found about $36 \%$ of patients had neurological manifestations [157]. This was more common in patients with severe cases and particularly for those with preconditions, such as CVD, including ischemic and haemorrhagic strokes and impaired consciousness [79]. Older patients with CVD and risk factors, such as hypertension, diabetes and higher levels of C-reactive protein compared to patients without CVD were at greater risk of severe COVID-19 symptoms and poorer prognosis [158]. Others reported that COVID-19 patients had clinical presentations of large-vessel ischemic stroke in young patients, acute necrotizing encephalopathy, encephalitis, meningitis, headaches and dizziness [81-91]. Patients with Parkinson's disease (PD) appear also to be affected by COVID-19 by exacerbating motor symptoms, such as tremor and dyskinesias, and reducing the efficacy of dopaminergic medication [159-162]. There is emerging evidence that there are psychological and behavioural changes (mental health) associated with COVID-19 infection due, perhaps, to the mitigating efforts to minimize the viral transmission, such as the isolation. There are changes in anxiety, sleep, mood, alcohol consumption and drug abuse $[163,164]$, and stress from the treatment of severe cases, post-traumatic stress syndrome and depression[165]. However, it's unclear if these clinical neurological presentations seen in COVID-19 patients are due to the virus entering brain or as a consequence of cardio-respiratory and multiorgan failure.

In some patents, COVID-19 is associated with thrombotic vascular events, such as strokes $[166,167]$. The incidence of strokes is 7.6-fold greater with COVID-19 compared to that of influenza infections [168]. There is a similar sevenfold increase in the incidence of large vessel stroke in young people with COVID-19 compared to the previous year's cases [169-173]. The incidence of cerebrovascular disease in COVID-19 patients is estimated at $1-6 \%,[169,174]$, and possible mechanisms include cytokine storm, hypercoagulation, endotheliitis and endotheliopathy. Viral particles are associated with the cerebrovasculature and the endothelium of other organs $[169,174,175]$. In severe endothelium injury; there is vascular thrombosis, microangiopathy and angiogenesis [176]. The raised plasma levels of von Willebrand factor and soluble thrombomodulin may indicate vascular injury [177]. Infiltration of leukocytes and intravascular coagulation may be due to compromised vascular integrity [175].

Neurological disorders were also associated with SARS and MERS. SARS was associated with seizures, myopathy, rhabdomyolysis and viral RNA in CSF and brain tissue $[178,179]$. MERS was also associated with neuropathy, delirium, acute cerebrovascular disease, confusion and seizure [180]. With the similarities between animal and human CoVs, both molecularly and symptomatically, possible mechanism for how SARS-CoV-2 behaves can be modeled. CoVs have been shown to invade, infect, and induce neurological-like disease in animal models of SARS and MERS [181-184]. It appears that neurotropism is a common feature of CoVs, and such neuroinvasion propensity of CoVs have been documented in almost all of the beta-CoVs (SARS, MERS, HCOV-229E, OC43) [103].

The impact of the SARS-CoV-2 and COVID-19 on CNS and the cerebrovasculature may be a minor and/or a secondary issue of the systemic inflammatory disease caused by the virus. The mortality of the disease is mostly due to the failure of lung, cardiovascular and kidney functions of the patients with underling diseases or those with immune dysfunction. A few cases may die from stroke as a result of thrombosis and thrombus embolization, but this could be a significant number of deaths from COVID-19-related neurological consequences, since the number of deaths from this infection is high. Currently there aren't data that SARS-CoV-2 impacts the cerebrovasculature of mild or asymptomatic cases as there isn't many of these cases that have been hospitalized. Further studies are needed.

\section{How could SARS-CoV-2 enter the brain?}

The exact mechanism of SARS-CoV-2 neuroinvasion is unclear. The main mode of $\mathrm{CoV}$ entry into the body is inhalation, and thus, the viruses access the nasal and buccal cavities. Viruses could enter the brain by retrograde 
transport via sensory nerve endings within these regions, such as the cranial olfactory and trigeminal, and the autonomic nervous system [98, 185]. In addition, virus that enters blood from the infected lungs may interact with the cerebrovasculature [27] and/or at the bloodCSF barrier, the choroid plexus [186]. Virus associated with leukocytes, such as monocytes, may enter the brain via receptors, such as advanced glycation endproducts (RAGE) and platelet endothelial cell adhesion molecule-1 (PECAM-1; CD31) $[64,187]$. There is also the possibility of viral neuroinvasion via the gastrointestinal tract [188].

\section{Olfactory bulb}

SARS-CoV-2 may access the olfactory epithelium and penetrate the cribriform plate to enter the olfactory bulb, and from there spreads within the CNS. It can infect neurons or non-neural cells via ACE2 and/or TMPRSS2 receptors and transported along the olfactory nerve [189]. SARS-CoV-2 interaction with the olfactory mucosa may explain the anosmia or hyposmia seen in COVID-19 patients. In addition to the olfactory nerve, it is possible the virus can use other nerves, such as the trigeminal and the vagus, which innervate the buccal cavity, respiratory tract and lungs [190, 191]. SARS-CoV-1, another CoV, also shows a transneural penetration through the olfactory bulb in a mouse model and thus SARS-CoV-2 might behave similarly [183]. (Figs. 3, 4).

\section{Cerebrovasculature}

Since the CNS vascular barriers are likely compromised in the severely infected patients and in the aging brain, especially in the more susceptible patient groups, SARS$\mathrm{CoV}-2$ interaction at the cerebrovasculature may potentiate its dysfunction. The leaky cerebrovascular can cause cerebral edema [192]. The local increase in interstitial pressure would decrease blood flow to the region, leading to neuronal dysfunction and cell death [105, 192]. SARS-CoV-2 induced inflammation of the meningeal cells could increase influx of fluid, which may activate resident perivascular macrophages and parenchymal microglia leading to aggravation of cerebral inflammation (Fig. 3). SARS-CoV-2 spike proteins interact with the in vitro models of the BBB[98], and slowly cross the murine cerebrovascularture via adsorptive transcytosis that is independently of ACE2 $(27 ; 281)$. Thus, further studies are needed to support significant neuroinvascion as the explanation for the neurological symptoms associated with COVID-19.

There are reports of possible SARS-CoV-2 neurotropism but further studies are needed to establish whether this is related to the degree of infection (viral load), the time this occurs in COVID-19 progression, conditions that may contribute to this and the frequency of its occurrence. Also, it is unknown whether this is due to the virus crossing the normal CNS vascular barrier to cause neuroinvasion or via the dysfunctional barriers as a consequence of pneumonia induced-hypoxia. There are reports of encephalitis, which was not due to COVID19-induced hypoxia [193] and brain cortical hyperintensity, as seen in MRI images, which may be due to viral infection [146, 194]. The virus was detected in the cortical brain tissue, which may suggest it enters brain [195]. SARS-CoV-2 is detected in the olfactory mucosa [196].

\section{How SARS-CoV-2 could spread within the brain}

Within the brain, SARS-CoV-2 may interact with and spread through the ACE2, other facilitator receptors or by adsorptive uptake by cells. In SARS patients, SARS particles were located almost exclusively in the neurons [103]. The brainstem was heavily infected by SARS and MERS [103], and thus, all CoVs may invade the brain [103]. Neurons can then take up the virus, which then binds to intracellular ACE2 [97]. ACE2 receptor is expressed in both neurons and glia cells [195], but mainly in the cytoplasm of neurons [97]. Most studies used in vitro models to determine whether SARS-CoV-2 infect neurons or inferred that there is a potential of infection by assessing the presence of ACE2 [197, 198]. However, SARS-CoV-2 was detected in cortical neurons of infectious patients [199]. This may explain the presence of SARS in neuronal cells. Trans-synaptic transfer has been documented for other CoVs, such as HEV67 [103] and avian bronchitis virus [96]. Murine $\mathrm{CoV}$ can replicate and cause direct lysis of oligodendrocytes and demyelination in the CNS during the acute phase[200, 201]. In mice, infected intranasally with a large load of neurovirulent strains of $\mathrm{HCoV}-\mathrm{OC} 43$, it entered the $\mathrm{CNS}$ via the olfactory nerves with subsequent trans-neuronal retrograde dissemination to distant connections of the olfactory bulb, and the pyriform cortex and brainstem [201, 202]. In MERS infected mice, the presence of the virus in the CNS was associated with high mortality [103]. Neuroanatomic interconnections indicate that the death of infected animals or patients may be due to the dysfunction of the cardiorespiratory center in the brainstem [103]. It was suggested that lipids may play a role in SARS-CoV-2 in brain [203]. However, there are no data to support any mechanism for the spread of SARS-CoV-2 in brain. (Figs. 4, 5, 6).

\section{Cytokine storm}

The "cytokine storm" is defined as cytokines released due to an overactive and dysregulated immune response to a different antigen, such as infections, which may lead to multiorgan dysfunction. In COVID19, cytokine storm is associated with patients with 


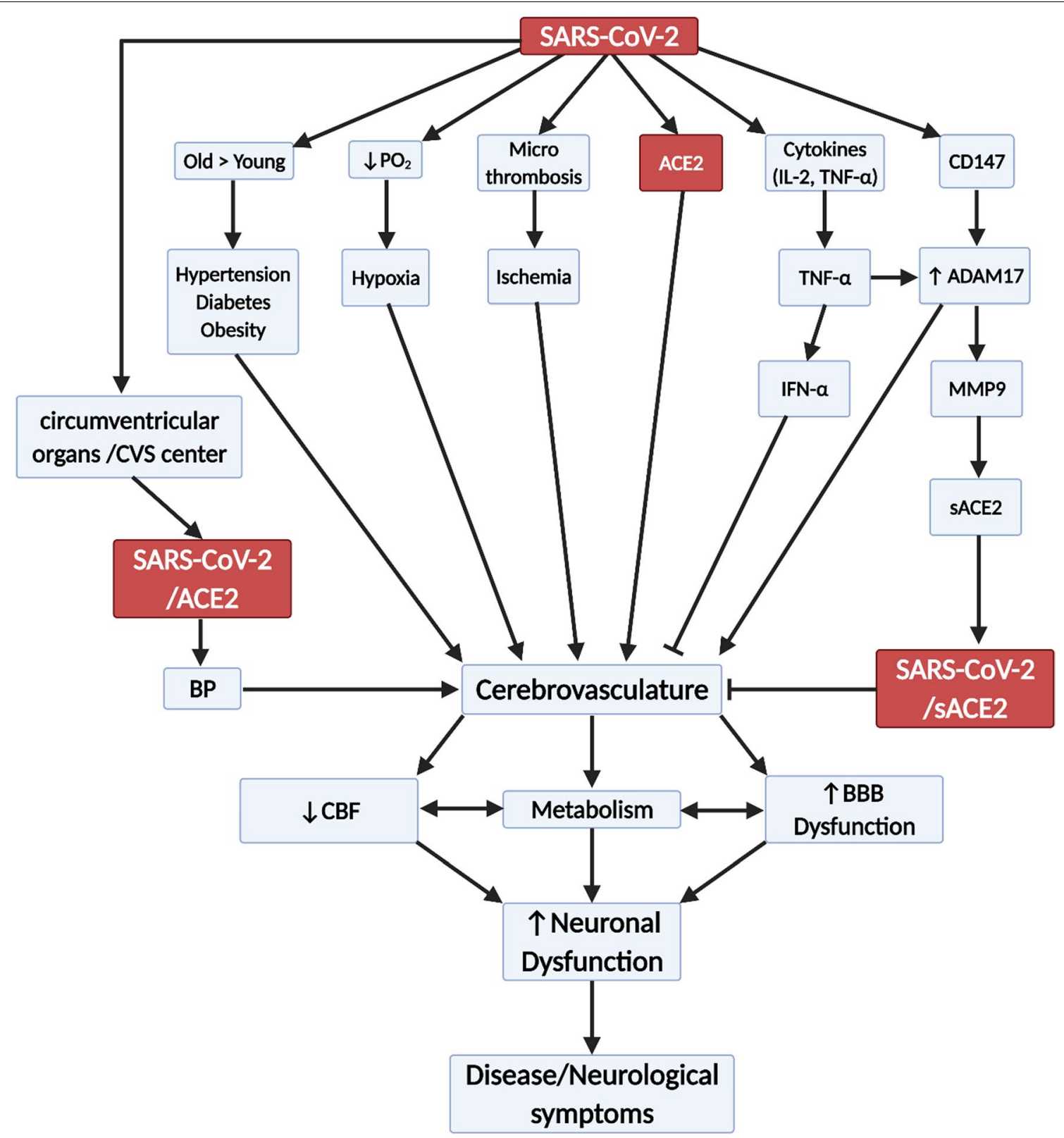

Fig. 6 Flow diagram showing possible effects of SARS-CoV-2 on the cerebrovasculature. CBF (cerebral blood flow), BBB (blood brain barrier), ACE2 (angiotensin converting enzyme 2), sACE2 (soluble ACE), IFN (interferon), CVS (cardiovascular centre), IL-1 (interleukin 1), TNFa (tumour necrosis factor a), CD147 (EMMPRIN (extracellular matrix metalloprotease inducer), ADAM17 (disintegrin and metalloprotease17), MMP9 (matrix metalloprotease 9), $\mathrm{BP}$ (blood pressure) and $\mathrm{pO}_{2}$ (partial pressure of oxygen)

severe illness and high concentrations of proinflammatory cytokines in plasma, especially interleukin (IL) 6, compared to moderately sick patients [204-208]. This is also associated with a poor prognosis in COVID19 [209]. In addition, the number of white blood cells, and levels of procalcitonin and C-reactive protein are higher in the intensive care unit (ICU) cases than in non-ICU cases [204-208, 210-212]. Cytokine storm can lead to apoptosis of epithelial cells, which may lead to vascular leakage [213].

In SARS, the levels of IL-6, IL-1 $\beta$, IFN, and CXCL10 are increased. These cytokines are secreted mainly by dendritic cells, neutrocytes and macrophages, indicating that the innate immunity is involved in SARS. Cytokines induce the infiltration and recruit proinflammatory cells. In SARS patients there is evidence of 
alveolar damage, edema and focal hemorrhage. These are also present in the manifestation of COVID-19 [214]. Since SARS-CoV and SARS-CoV-2 infect cells using mainly the same receptor (ACE2), it is possible that both viruses can affect the same immune cells and cause a cytokine storm [215-226]. Cytokines can cross the BBB, and also disrupt its integrity [149, 227-230].

\section{Co-morbidities increase risk of death from COVID-19: outlined}

According to the CDC, 91.7\% of COVID-19 confirmed hospitalized cases had at least one reported underlying medical condition. The most common preconditions associated with COVD-19 hospitalization were hypertension and obesity. However, $22 \%$ of those hospitalized had some form of neurological disease, and this was greater than hospitalized cases of asthma ( 13\%), [231]. Chronic hypertension has been linked to cerebrovascular dysfunction and deficient local perfusion [232]. Thus, it's tempting to speculate that this significant group of patients may also include those with persistent post-infection symptoms ("long-haulers"). Further work is needed on this group of patients ([233].

There are a number of underlying conditions associated with a dysfunctional cerebrovasculature, which may make it more susceptible to SARS-CoV-2 infection and therefore, greater severity of COVID-19. While it is difficult to isolate each pre-condition as many overlaps in the patient pool, there is evidence that each one individually alters the abilities of the CNS vascular barriers to protect the brain (Fig. 5). The CNS vascular barriers are dysfunctional, both structurally and functionally with aging. The cerebrovasculature becomes leakier, with reduced capillary density, glucose transport and cerebral blood flow [105, 234]. Increased cerebrovascular MMP activities via CD147/ADAM17 breakdown the basement membrane and contribute to the vascular dysfunction [235, 236]. Proinflammatory cytokines, such as TNF $\alpha$ could stimulate ADAM17[69]. CD147 is expressed on the endothelium, astrocytes and astrocytes endfeet [237]. SARS-CoV-2/SP interaction with CD147 could increase MMP9 activity, which may break down the basement membrane leading to loss of pericyte coverage and tight junction proteins and thus, aggravate cerebrovascular dysfunction [101]. Hyperglycemia, as seen in diabetes, is associated with increased MMP activity [238]. Recently, it was shown that recombinant SP of SARS-CoV-2 interact with CD147 to disrupt the function of cardiac pericyte-endothelial cells [25]. Thus, MMP9 could be targeted as a possible additional therapy for COVID-19 (Fig. 6).

\section{Age}

Age is a major risk factor for the development of a number of disorders affecting the brain, e.g., Alzheimer's disease [105, 239-242]. As cells aged, they transition to a state of senescence, which decreases the chance of forming malignancies, and this is associated with moving to a more "inflamed state" [105, 107, 240, 243]. Aged and/ or senescence cells have a myriad of changes that cause alteration in their phenotypical expression, which is associated both with an increase in circulating factors that are harmful to the CNS and decreases in factors that are protective [244]. There is an increase in cerebrovascular disruption through factors that induce caveolae-cytoskeleton interactions that result in increased fluid phase pinocytosis [245]. Aging causes a pro-inflammatory environment in the CNS, leading to reactive oxygen species (ROS), an increase in senescence cells and an increase in the number of reactive microglia and astrocytes [240]. In aging, microglia processes retract and thicken, cell bodies enlarge, and astrocytes increase expression of inflammatory surface markers [246]. This reflects a chronic, low-grade neuro-inflammation and these glia cells have a heightened response to immune stimulation. There is significant reduction in occludin expression in brain endothelium and this leads to exacerbation of neuroinflammation and leakage of harmful molecules into the brain [240, 243, 247]. Aged endothelial cells have altered expression and function of many of the important transporter and efflux proteins that help regulate the brain's environment. Aging rodents showed reduced brain glucose uptake, and a reduction in GLUT1 expression was associated with impaired glucose utilization and neuronal damage [248]. Reduced pericytes coverage on the aging cerebrovasculature leads to its dysfunction. Efflux transporters, such as LRP-1 and P-gp, important in the clearing of toxic products from brain, are shown to be down regulated with aging $[242,249,250]$.

\section{Obesity}

According to the CDC, $50 \%$ of hospitalized patients with confirmed COVID-19 were obese and $\sim 28 \%$ were overweight. Over $42.0 \%$ of American adults are considered obese [231, 251]. Obesity has widespread biological changes, such as altered levels of hormones that regulate feeding (principally insulin, leptin, adiponectin and ghrelin). These hormones are known to cross the cerebrovasculature via specialized transporters $[27,135]$. Obesity is linked to increase in neuroinflammation and neuronal loss in areas of the brain (arcuate nucleus and lateral hypothalamus) that have a high metabolism [109, 114, 252]. In mice fed a high fat diet (HFD), there is disruption of the cerebrovasculature and tanycytes expression 
of transporters [252]. HFD increased activation of astrocytes and microglia, decreased tight junction proteins (claudins-5 and -12), increased permeability and downregulated cytoskeleton proteins (vimentin and tubulin) [109, 253-255]. HFD increased leukocytes penetration across the vasculature as well as increased inflammatory cytokine production, which can cross the vasculature leading to a cycle of neuroinflammation, decrease in barrier properties and increasing its damage.

\section{Diabetes Mellitus}

Metabolic disorders as an underlying condition increased the prevalence of COVID-19 confirmed hospitalizations $[231,256]$. In the USA, $11 \%$ of Americans have diabetes mellitus (DM). Neurological and cognitive issues, such as dementia, as well as vascular disorders, such as stroke, are documented in DM. Diabetic encephalopathy, a progressive complication of diabetes, has been linked to the increase probability of neurological related disorders. These are related to macrovascular and microvascular injury due to endothelial dysfunction [257, 258]. In vitro and in vivo studies have shown that hyperglycemia is a primary driver for detrimental effects on vascular endothelial cells and microvascular injury underlies the classic pathology of DM [259]. Vascular damage seems to occur from excess glucose concentration within the endothelial cells, causing excessive ROS and damage to mitochondria [257, 258]. The NVU shows sign of modification due to hyperglycemia, with increase in basement membrane thickness, pericyte degeneration and increase in markers in the brain parenchyma due to barrier breakdown [258]. Collectively, these changes at the CNS vascular barriers could aggravate SARS-CoV-2 cerebral effects.

\section{Hypertension}

Hypertension is associated with an increased incidence of confirmed COVID-19 cases [231]. The cerebrovasculature has been shown to be disrupted in cardiovascular disease, such as neurogenic hypertension [10, 260]. The RAS system is a major contributor to cardiovascular disease and hypertension. Angiotensin II has been shown to induce oxidative stress and inflammation, and appears to precede hypertension [10]. In hypertensive rats, there are decreased levels of the tight junction components (occludin and ZO-1). This hypertension is related to chronic, low grade inflammation in the brain and the release of circulating inflammatory molecules [10, 260]. Circulating inflammatory factors and inflammatory cells could enter the CNS and contribute to the adverse effects. In addition, astrocytes and microglia can release a myriad of chemokines and cytokines, which can increase the recruitment of leukocytes and increase vascular disruption [260] (Fig. 6).

\section{Conclusions}

There are many possible ways the virus can affect the brain. The main way is due to dyspnea and thromboembolism that deprive the brain of oxygen and blood, and can lead to cerebral edema. Depending on the viral load, it can enter brain via retrograde transport along nerve endings in the buccal and nasal cavities, the main route of entry of the virus into the body. While the levels of SARSCoV-2 in blood is low, from blood the virus can enter the brain via the normal or dysfunctional vasculature and access cells within brain, which express receptors that can interact with this virus. Interaction with ACE2 and/ or CD147 on cells of the NVU could activate MMP9 that would break down the basement membrane, and render pericytes dysfunctional. The SP can slowly cross the cerebrovasculature via absorptive transcytosis, but not by ACE2. Entry into the CSF via the choroid plexus could distribute the virus to brain along the CSF drainage route. Virus could also enter brain with the trafficking of leukocytes. Thus, the aging brain may be a neurovascular target of SARS-CoV-2 with potentially devastating consequences, but there is no sound evidence of major neuroinvasion. In addition, the significance of neuroinvasion to the disease outcome in unclear since there is overwhelming respiratory failure in patients from which brain samples were tested for SARS-CoV-2. A long-term effect of this viral infection may be neurodegeneration and behavioral changes. A better understanding of the SARS$\mathrm{CoV}-2$ on the aging vasculature could help in health care management of these susceptible patients and assist in the development of therapies that target the virus to prevent severe outcomes from COVID-19.

\section{Abbreviations}

ACE: Angiotensin converting enzyme; ACE2: Angiotensin converting enzyme (ACE) 2 receptors; ARDS: Acute respiratory distress syndrome; ADAM17: A disintegrin and metalloprotease 17; ANE: Acute necrotizing encephalopathy; AT1: Angiotensin receptor 1; BBB: Blood-brain barrier; BP: Blood pressure; CD147: EMMPRIN (extracellular matrix metalloprotease inducer); CDC: Enter of Disease Control; Cov: Coronavirus; COVID-19: Coronovirus December 2019; CSF: Cerebrospinal fluid; CNS: Central nervous system; CT: Computer tomography; HCoV-NL63: Human coronavirus NL63; HCoV-2295: Human coronavirus 2295; HFD: High fat diet; GLUT1: Glucose transporter 1; LRP-1: Low- density lipoprotein-related receptor 1; MERS-CoV: Middle East Respiratory Syndrome CoV;MMP9:matrix metalloprotease 9;NVU: neurovascular unit; PECAM-1: Platelets endothelial cell adhesion molecule-1 (CD31); RAGE: Receptor for advanced glycation end products; RAS: Renin angiotensin system; RNA: Ribonucleic acid; RT-PCR: Reverse transcription polymerase chain reaction; SARS: Severe acute respiratory syndrome; SARS-CoV: Severe acute respiratory syndrome-CoV; SARS-CoV-2: Severe acute respiratory syndrome-CoV-2; ROS: Reactive oxygen species; TMPRESS 2: Transmembrane protease, serine.

\section{Acknowledgements}

Funding from the $\mathrm{NIH}$ (AG05774 and AG050212 to RD). 


\section{Authors' contributions}

$\mathrm{RD}$ designed the review; $\mathrm{CMQ}$ and $\mathrm{RD}$ wrote the review; MB reviewed the manuscript and prepared references; CMQ prepared figures and references. All authors read and approved the final manuscript.

\section{Funding}

From the NIH (AG05774 and AG050212 to RD).

\section{Availability of data and materials}

Not applicable as this is a review manuscript.

\section{Declarations}

Ethics approval and consent to participate:

Not applicable.

\section{Consent for publication}

Not applicable.

\section{Competing interests}

The authors declare that they have no competing interests.

Received: 10 June 2021 Accepted: 6 July 2021

Published online: 14 July 2021

\section{References}

1. Coronavirus Update (Live): $122,818,961$ Cases and 2,711,620 Deaths from COVID-19 Virus Pandemic-Worldometer [Internet]. https://www. worldometers.info/coronavirus/?utm_campaign=homeAdvegas 1 ?. Accessed 19 Mar 2021.

2. Pascarella G, Strumia A, Piliego C, Bruno F, Del Buono R, Costa F, et al. COVID-19 diagnosis and management: a comprehensive review. J Intern Med. 2020;288:192-206.

3. Tenforde MW, Kim SS, Lindsell CJ, Billig Rose E, Shapiro NI, Files DC, et al. Symptom duration and risk factors for delayed return to usual health among outpatients with COVID-19 in a multistate health care systems network-United States, March-June 2020. MMWR Morb Mortal Wkly Rep. 2020;69(30):993-8.

4. Carfi A, Bernabei R, Landi F. Persistent symptoms in patients after acute COVID-19. JAMA. 2020;324:603-5.

5. Kirby T. COVID-19 survivor experiencing long-term symptoms. Lancet Respir Med. 2021:9:570-2.

6. Miyazato Y, Morioka S, Tsuzuki S, Akashi M, Osanai Y, Tanaka K, et al. Prolonged and late-onset symptoms of coronavirus disease 2019. Open Forum Infect Dis. 2020;7(11):ofaa507.

7. WHO |World Health Organization [Internet]. 2020. https://www.who. int/. Accessed 15 June 2020.

8. Centers for Disease Control and Prevention [Internet]. 2020. https:// www.cdc.gov/. Accessed 15 June 2020.

9. Dalan R, Bornstein SR, El-Armouche A, Rodionov RN, Markov A, Wielockx B, et al. The ACE-2 in COVID-19: foe or friend? Horm Metab Res. 2020;52(05):257-63.

10. Dinh QN, Drummond GR, Sobey CG, Chrissobolis S. Roles of inflammation, oxidative stress, and vascular dysfunction in hypertension. BioMed Res Int. 2014. https://doi.org/10.1155/2014/406960.

11. Xu X, Chen P, Wang J, Feng J, Zhou H, Li X, et al. Evolution of the novel coronavirus from the ongoing Wuhan outbreak and modeling of its spike protein for risk of human transmission. Sci China Life Sci. 2020;63(3):457-60.

12. Yi Y, Lagniton PNP, Ye S, Li E, Xu RH. COVID-19: what has been learned and to be learned about the novel coronavirus disease. Int J Biol Sci NLM (Medline). 2020;16:1753-66.

13. Gordon DE, Jang GM, Bouhaddou M, Xu J, Obernier K, White KM, et al. A SARS-CoV-2 protein interaction map reveals targets for drug repurposing A SARS-CoV-2 protein interaction map reveals targets for drug repurposing. Nature. 2020:583:459-68.
14. 'Li Y, Zhou W, Yang L, You R. Physiological and pathological regulation of ACE2, the SARS-COV-2 receptor. Pharmacol Res 2020;157(January):19-20.

15. Coronavirus Update (Live): COVID-19 Virus Pandemic-Worldometer [Internet]. 2020. https://www.worldometers.info/coronavirus/. Accessed 20 May 2020.

16. Viner RM, Whittaker E. Kawasaki-like disease: emerging complication during the COVID-19 pandemic. Lancet. 2020;395:1741-3.

17. Ramphul K, Mejias SG. Kawasaki disease: a comprehensive review. Arch Med Sci Atheroscler Dis. 2018;3(1):41-5.

18. Li Y, Zhou W, Yang L, You R. Physiological and pathological regulation of ACE2, the SARS-CoV-2 receptor. Pharmacol Res. 2020;157:104833.

19. Ya M. Properties of coronavirus and SARS-CoV-2. Malays J Pathol. 2020;42(1):3-11.

20. Xiao K, Zhai J, Feng Y, Zhou N, Zhang X, Zou J-J, et al. Isolation of SARS-CoV-2-related coronavirus from Malayan pangolins. Nature. 2020;583:286-9.

21. Das G, Mukherjee N, Ghosh S. Neurological Insights of COVID-19 Pandemic. ACS Chem Neurosci. 2020;11(9):1206-9.

22. Ortega JT, Serrano ML, Pujol FH, Rangel HR. Role of changes in SARSCoV-2 spike protein in the interaction with the human ACE2 receptor: an in silico analysis. EXCLI J. 2020;19:410-7.

23. Perrotta F, Matera MG, Cazzola M, Bianco A. Severe respiratory SARS-CoV2 infection: Does ACE2 receptor matter? Respir Med. 2020;168:105996

24. Wang K, Chen W, Zhou Y-S, Lian J-Q, Zhang Z, Du P, et al. SARS-CoV-2 invades host cells via a novel route: CD147-spike protein. bioRxiv. 2020 Mar 14;2020.03.14.988345.

25. Avolio E, Gamez M, Kapil Gupta ; Foster R, Berger I, Caputo M, et al. The SARS-CoV-2 spike protein disrupts the cooperative function of human cardiac pericytes - endothelial cells through CD147 receptor-mediated signalling: a potential non-infective mechanism of COVID-19 microvascular disease. https://doi.org/10.1101/2020.12.21.423721

26. Alejandra Tortorici M, Walls AC, Lang Y, Wang C, Li Z, Koerhuis D, et al. Structural basis for human coronavirus attachment to sialic acid receptors. Nat Struct Mol Biol. 2019;26(6):481-9.

27. Rhea EM, Logsdon AF, Hansen KM, Williams LM, Reed MJ, Baumann KK, et al. The S1 protein of SARS-CoV-2 crosses the blood-brain barrier in mice. Nat Neurosci. 2020;24(3):368-78. https://doi.org/10.1038/ s41593-020-00771-8.

28. Rathnasinghe R, Jangra S, Cupic A, Martínez-Romero C, Mulder LCF, Kehrer T, et al. The N501Y mutation in SARS-CoV-2 spike leads to morbidity in obese and aged mice and is neutralized by convalescent and post-vaccination human sera Contributed equally. medRxiv. 2021;2021.01.19.21249592.

29. Volz E, Hill V, McCrone JT, Price A, Jorgensen D, O'Toole Á, et al. Evaluating the effects of SARS-CoV-2 spike mutation D614G on transmissibility and pathogenicity. Cell. 2021;184(1):64-75.e11.

30. Korber B, Fischer WM, Gnanakaran S, Yoon H, Theiler J, Abfalterer W, et al. Tracking changes in SARS-CoV-2 spike: evidence that D614G increases infectivity of the COVID-19 virus. Cell. 2020;182(4):812-827. e19.

31. Yang X, Chen X, Bian G, Tu J, Xing Y, Wang Y, et al. Proteolytic processing, deubiquitinase and interferon antagonist activities of Middle East respiratory syndrome coronavirus papain-like protease. J Gen Virol. 2014;95(PART3):614-26.

32. Plante JA, Liu Y, Liu J, Xia H, Johnson BA, Lokugamage KG, et al. Spike mutation D614G alters SARS-CoV-2 fitness. Nature. 2020:592:116-21.

33. Hou YJ, Chiba S, Halfmann P, Ehre C, Kuroda M, Dinnon KH, et al. SARSCoV-2 D614G variant exhibits efficient replication ex vivo and transmission in vivo. Science. 2021;370(6523):1464-8.

34. Andrew Rambaut, Nick Loman, Oliver Pybus, Wendy Barclay, Jeff Barrett, Alesandro Carabelli, Tom Connor, Tom Peacock, David L Robertson EV. Preliminary genomic characterisation of an emergent SARS-CoV-2 lineage in the UK defined by a novel set of spike mutations - SARS-CoV-2 coronavirus / nCoV-2019 Genomic Epidemiology - Virological [Internet]. COVID-19 Genomics Consortium UK. 2021. https://virological.org/t/ preliminary-genomic-characterisation-of-an-emergent-sars-cov-2-linea ge-in-the-uk-defined-by-a-novel-set-of-spike-mutations/563. Accessed 6 Feb 2021 
35. SARS-CoV-2 Variants of Concern | CDC [Internet]. 2021. https://www cdc.gov/coronavirus/2019-ncov/cases-updates/variant-surveillance/ variant-info.html. Accessed 7 Feb 2021.

36. Greaney AJ, Loes AN, Crawford KH, Starr TN, Malone KD, Chu HY, et al. Comprehensive mapping of mutations to the SARS-CoV-2 receptorbinding domain that affect recognition by polyclonal human serum antibodies. bioRxiv. 2021 Jan 4;2020.12.31.425021.

37. Avanzato VA, Matson MJ, Seifert SN, Pryce R, Williamson BN, Anzick $\mathrm{SL}$, et al. Case study: prolonged infectious SARS-CoV-2 shedding from an asymptomatic immunocompromised individual with cancer. Cell. 2020;183(7):1901-1912.e9.

38. Lauring AS, Hodcroft EB. Genetic variants of SARS-CoV-2 - what do they mean? JAMA. 2021;325:529-31.

39. WHO | SARS-CoV-2 mink-associated variant strain-Denmark. WHO. 2020.

40. Maison DP, Ching LL, Shikuma CM, Nerurkar VR. Genetic Characteristics and Phylogeny of 969-bp S Gene Sequence of SARS-CoV-2 from Hawaii Reveals the Worldwide Emerging P681H Mutation. bioRxiv. 2021 Jan 7;2021.01.06.425497.

41. Wang R, Chen J, Gao K, Hozumi Y, Yin C, Wei G-W. Analysis of SARSCoV-2 mutations in the United States suggests presence of four substrains and novel variants. Commun Biol. 2021;4(1):228.

42. Yu YJ, Zhang Y, Kenrick M, Hoyte K, LukW, Lu Y, et al. Boosting brain uptake of a therapeutic antibody by reducing its affinity for a transcytosis target. Sci Transl Med 2011;3(84):84ra44-84ra44.

43. Spinato G, Fabbris C, Polesel J, Cazzador D, Borsetto D, Hopkins C, et al. Alterations in smell or taste in mildly symptomatic outpatients with SARS-CoV-2 infection. JAMA. 2020;323:2089-90.

44. Johnson RH, Kho DT, O' Carroll SJ, Angel CE, Graham ES. The functional and inflammatory response of brain endothelial cells to Toll-Like Receptor agonists OPEN. www.nature.com/scientificreports.

45. Mallard C. Innate immune regulation by toll-like receptors in the brain. International Scholarly Research Network ISRN Neurology. 2012.

46. Hollidge BS, Cohen CA, Frimpong A, Badger CV, Dye JM, Schmaljohn CS. Toll-like receptor 4 mediates blood-brain barrier permeability and disease in $\mathrm{C} 3 \mathrm{H}$ mice during Venezuelan equine encephalitis virus infection Venezuelan equine encephalitis virus and toll-like receptor 4 Virulence. 2021. https://doi.org/10.1080/21505594.2020.1870834.

47. Rouse BT, Sehrawat S. Immunity and immunopathology to viruses: What decides the outcome? Nat Rev Immunol. 2010;10:514-26.

48. See H, Wark P. Innate immune response to viral infection of the lungs. Paediatr Respir Rev. 2008;8:243-50.

49. Verity R, Okell LC, Dorigatti I, Winskill P, Whittaker C, Imai N, et al. Estimates of the severity of coronavirus disease 2019: a model-based analysis. Lancet Infect Dis. 2020;20(6):669-77.

50. Ousman SS, Kubes P. Immune surveillance in the central nervous system. Nat Neurosci. 2012;15:1096-101.

51. Vabret N, Britton GJ, Gruber C, Hegde S, Kim J, Kuksin M, et al. Immunology of COVID-19: Current state of the science. Immunity. 2020;52:910-41.

52. Channappanavar R, Fehr AR, Zheng J, Wohlford-Lenane C, Abrahante JE, Mack M, et al. IFN-I response timing relative to virus replication determines MERS coronavirus infection outcomes. J Clin Investig. 2019;129(9):3625-39.

53. Salama C, Han J, Yau L, Reiss WG, Kramer B, Neidhart JD, et al. Tocilizumab in patients hospitalized with covid-19 pneumonia. N Engl J Med. 2021;384(1):20-30

54. Engelhardt B, Ransohoff RM. The ins and outs of T-lymphocyte trafficking to the CNS: anatomical sites and molecular mechanisms. Trends Immunol. 2005;26:485-95.

55. Kumar D, Jahan S, Khan A, Jamal Siddiqui A, Singh Redhu N, Khan J, et al. Neurological manifestation of SARS-CoV-2 induced inflammation and possible therapeutic strategies against COVID-19. 2035. https://doi. org/10.1007/s12035-021-02318-9

56. Zhang C, Wu Z, Li JW, Zhao H, Wang GQ. The cytokine release syndrome (CRS) of severe COVID-19 and Interleukin-6 receptor (IL-6R) antagonist Tocilizumab may be the key to reduce the mortality. Int J Antimicrob Agents. 2020;55(5).

57. Connors JM, Levy JH. Thromboinflammation and the hypercoagulability of COVID-19. J Thromb Haemostasis 2020
58. Rodríguez A, Tjärnlund A, Ivanji J, Singh M, García I, Williams A, et al. Role of IgA in the defense against respiratory infections: IgA deficient mice exhibited increased susceptibility to intranasal infection with Mycobacterium bovis BCG. Vaccine. 2005;23(20):2565-72.

59. Zuo Y, Kanthi Y, Knight JS. Neutrophil extracellular traps in COVID-19. JCI Insight. 2020. https://doi.org/10.1172/jci.insight.138999DS1.

60. Drescher B, Bai F. Neutrophil in viral infections, friend or foe? Virus Res. 2013;171(1):1-7. https://doi.org/10.1016/j.virusres.2012.11.002.

61. Allen $L-A H$, Anes $E$, Jonsson $C B, C a m p ~ J ~ v$. A role for neutrophils in viral respiratory disease. Article. 2017;8:1. Www.frontiersin.org

62. Chen HD, Fraire AE, Joris I, Welsh RM, Selin LK. Specific history of heterologous virus infections determines anti-viral immunity and immunopathology in the lung. American Journal of Pathology [Internet]. 2003 Oct 1. 163(4):1341-55. https://pubmed.ncbi.nlm.nih.gov/14507643/. Accessed 6 June 2021.

63. Tay MZ, Poh CM, Rénia L, MacAry PA, Ng LFP. The trinity of COVID19: immunity, inflammation and intervention. Nat Rev Immunol. 2020;28:1-12.

64. Yilla M, Harcourt BH, Hickman CJ, McGrew M, Tamin A, Goldsmith CS, et al. SARS-coronavirus replication in human peripheral monocytes/ macrophages. Virus Res. 2005;107(1):93-101.

65. Campillo-Navarro M, Chávez-Blanco AD, Wong-Baeza I, Serafín-López J, Flores-Mejía R, Estrada-Parra S, et al. Mast cells in lung homeostasis: Beyond type i hypersensitivity. Corp Commun. 2005;10(2):115-23.

66. Wysocka MB, Pietraszek-Gremplewicz K, Nowak D. The role of apelin in cardiovascular diseases, obesity and cancer. Vol. 9, Frontiers in Physiology. Frontiers Media S.A.; 2018.

67. Margolius HS. Kallikreins and Kinins. Hypertension. 1995;26(2):221-9.

68. Kuba K, Imai Y, Penninger JM. Multiple functions of angiotensinconverting enzyme 2 and its relevance in cardiovascular diseases. Circ J. 2013;77:301-8.

69. Haga S, Yamamoto N, Nakai-Murakami C, Osawa Y, Tokunaga K, Sata T, et al. Modulation of TNF-a-converting enzyme by the spike protein of SARS-COV and ACE2 induces TNF-a production and facilitates viral entry. Proc Natl Acad Sci USA. 2008;105(22):7809-14.

70. Swärd P, Edsfeldt A, Reepalu A, Jehpsson L, Rosengren BE, Karlsson MK. Age and sex differences in soluble ACE2 may give insights for COVID19. Crit Care. 2020;24:221.

71. Beneteau-Burnat B, Baudin B, Morgant G, Baumann FC, Giboudeau J. Serum angiotensin-converting enzyme in healthy and sarcoidotic children: Comparison with the reference interval for adults. Clin Chem. 1990:36(2):344-6.

72. Li W, Moore MJ, Vasllieva N, Sui J, Wong SK, Berne MA, et al. Angiotensin-converting enzyme 2 is a functional receptor for the SARS coronavirus. Nature. 2003;426(6965):450-4.

73. Lambert DW, Yarski M, Warner FJ, Thornhill P, Parkin ET, Smith Al, et al. Tumor necrosis factor-a convertase (ADAM17) mediates regulated ectodomain shedding of the severe-acute respiratory syndrome-coronavirus (SARS-CoV) receptor, angiotensin-converting enzyme-2 (ACE2). J Biol Chem. 2005;280(34):30113-9.

74. Patel VB, Clarke N, Wang Z, Fan D, Parajuli N, Basu R, et al. Angiotensin II induced proteolytic cleavage of myocardial ACE2 is mediated by TACE/ ADAM-17: a positive feedback mechanism in the RAS. J Mol Cell Cardiol. 2014;1 (66):167-76.

75. Lan J, Ge J, Yu J, Shan S, Zhou H, Fan S, et al. Structure of the SARS-CoV-2 spike receptor-binding domain bound to the ACE2 receptor. Nature. 2020;581(7807):215-20.

76. Sun P, Lu X, Xu C, Wang Y, Sun W, Xi J. CD-sACE2 inclusion compounds: an effective treatment for coronavirus disease 2019 (COVID-19). J Med Virol. 2020;92:1721-3.

77. Swärd P, Edsfeldt A, Reepalu A, Jehpsson L, Rosengren BE, Karlsson MK. Age and sex differences in soluble ACE2 may give insights for COVID19. Crit Care. 2020;24:1-3.

78. Hoffmann M, Kleine-Weber H, Schroeder S, Mü MA, Drosten C, Pö S. SARS-CoV-2 cell entry depends on ACE2 and TMPRSS2 and is blocked by a clinically proven protease inhibitor. Cell. 2020;181:271-80.

79. McKinley MJ, Albiston AL, Allen AM, Mathai ML, May CN, McAllen RM, et al. The brain renin-angiotensin system: Location and physiological roles. Int J Biochem Cell Biol. 2003;35:901-18.

80. Carey RM. The intrarenal renin-angiotensin system in hypertension. Adv Chronic Kidney Dis. 2015;22:204-10. 
81. Alenina N, Bader M. ACE2 in brain physiology and pathophysiology: evidence from transgenic animal models. Neurochem Res. 2019:44(6):1323-9.

82. Zhang Q, Cong M, Wang N, Li X, Zhang H, Zhang K, et al. Association of angiotensin-converting enzyme 2 gene polymorphism and enzymatic activity with essential hypertension in different gender a case-control study. Medicine. 2018;97(42):e12917

83. Evans CE, Miners JS, Piva G, Willis CL, Heard DM, Kidd EJ, et al. ACE2 activation protects against cognitive decline and reduces amyloid pathology in the Tg2576 mouse model of Alzheimer's disease. Acta Neuropathol. 2020;139(3):485-502.

84. Li L-J, Zhang F-B, Liu S-Y, Tian Y-H, Le F, Wang L-Y, et al. Human sperm devoid of germinal angiotensin-converting enzyme is responsible for total fertilization failure and lower fertilization rates by conventional in vitro fertilization. Biol Reprod. 2014;90(6):125.

85. Hemnes AR, Rathinasabapathy A, Austin EA, Brittain EL, Carrier EJ, Chen $X$, et al. A potential therapeutic role for angiotensin-converting enzyme 2 in human pulmonary arterial hypertension. Eur Respir J. 2018;51(6):1702638.

86. Soler MJ, Wysocki J, Batlle D. ACE2 alterations in kidney disease. Nephrol Dial Transplant. 2013;28(11):2687-97.

87. Chen Y, Liu Q, Guo D. Emerging coronaviruses: genome structure, replication, and pathogenesis. J Med Virol. 2020;92:418-23.

88. Imai Y, Kuba K, Rao S, Huan Y, Guo F, Guan B, et al. Angiotensinconverting enzyme 2 protects from severe acute lung failure. Nature. 2005;436(7047):112-6.

89. Da Silva JS, Gabriel-Costa D, Wang H, Ahmad S, Sun X, Varagic J, et al Blunting of cardioprotective actions of estrogen in female rodent heart linked to altered expression of cardiac tissue chymase and ACE2. J Renin-Angiotensin-Aldosterone Syst 2017. Doi: https://doi.org/10.1177/ 1470320317722270

90. Hamming I, Timens W, Bulthuis MLC, Lely AT, Navis GJ, van Goor H. Tissue distribution of ACE2 protein, the functional receptor for SARS coronavirus. A first step in understanding SARS pathogenesis. J Pathol. 2004:203(2):631-7.

91. Xu D, Ma M, Xu Y, Su Y, Ong S-B, Hu X, et al. Single-cell transcriptome analysis indicates new potential regulation mechanism of ACE2 and NPs signaling among heart failure patients infected with SARS-CoV-2 2 3

92. $\mathrm{Xu} \mathrm{H}$, Zhong L, Deng J, Peng J, Dan H, Zeng $X$, et al. High expression of ACE2 receptor of 2019-nCoV on the epithelial cells of oral mucosa. Int J Oral Sci. 2020;12(1):1-5.

93. Sakima A, Averill DB, Gallagher PE, Kasper SO, Tommasi EN, Ferrario $\mathrm{CM}$, et al. Impaired heart rate baroreflex in older rats: role of endogenous angiotensin-(1-7) at the nucleus tractus solitarii. Hypertension. 2005;46(2):333-40.

94. Elased KM, Cunha TS, Gurley SB, Coffman TM, Morris M. New mass spectrometric assay for angiotensin-converting enzyme 2 activity. Hypertension. 2006;47(5):1010-7.

95. Kabbani N, Olds JL. Does COVID19 infect the brain? If so, smokers might be at a higher risk. Mol Pharmacol. 2020;97:351-3.

96. Mankad K, Perry MD, Mirsky DM, Rossi A. COVID-19: a primer for neuroradiologists. Neuroradiology. 2020;62:647-8.

97. Doobay MF, Talman LS, Obr TD, Tian X, Davisson RL, Lazartigues E. Differential expression of neuronal ACE2 in transgenic mice with overexpression of the brain renin-angiotensin system. Am J Physiol Regul Integr Comp Physiol. 2007;292(1):R373-81.

98. Buzhdygan TP, DeOre BJ, Baldwin-Leclair A, BullockTA, McGary HM, Khan JA, et al. The SARS-CoV-2 spike protein alters barrier function in 2D static and 3D microfluidic in-vitro models of the human blood-brain barrier. Neurobiol Dis. 2020;146:105131.

99. Horby P, Lim WS, Emberson J, Mafham M, Bell J, Linsell L, et al. Effect of dexamethasone in hospitalized patients with COVID-19: preliminary report. medRxiv. 2020 Jun 22:2020.06.22.20137273.

100. Ghobrial M, Charish J, Takada S, Valiante T, Monnier PP, Radovanovic I, et al. The human brain vasculature shows a distinct expression pattern of SARS-CoV-2 entry factors. bioRxiv. 2020.

101. He L, Mäe MA, Sun Y, Muhl L, Nahar K, Liébanas EV, et al. Pericyte-specific vascular expression of SARS-CoV-2 receptor ACE2-implications for microvascular inflammation and hypercoagulopathy in COVID-19 patients. bioRxiv. 2020 May 12;2020.05.11.088500.
102. Ou X, Liu Y, Lei X, Li P, Mi D, Ren L, et al. Characterization of spike glycoprotein of SARS-CoV-2 on virus entry and its immune cross-reactivity with SARS-CoV. Nat Commun. 2020;11(1):1620.

103. LiY, Bai W, Hashikawa T. The neuroinvasive potential of SARS-CoV2 may play a role in the respiratory failure of COVID-19 patients. J Med Virol. 2020;92(6):552-5

104. Li Y, Zhang Z, Yang L, Xin S, Cao P, Lu J. The MERS-CoV receptor DPP4 as a candidate binding target of the SARS-CoV-2 spike. 2020;

105. Zlokovic BV. The Blood-Brain Barrier in Health and Chronic Neurodegenerative Disorders. Neuron. 2008;57:178-201.

106. Wong AD, Ye M, Levy AF, Rothstein JD, Bergles DE, Searson PC. The blood-brain barrier: an engineering perspective. Front Neuroeng. 2013;6(JUL):1-22.

107. Zlokovic BV. Neurovascular mechanisms of Alzheimer's neurodegeneration. Trends Neurosci. 2005;28(4):202-8.

108. Schlageter KE, Molnar P, Lapin GD, Groothuis DR. Microvessel organization and structure in experimental brain tumors: Microvessel populations with distinctive structural and functional properties. Microvasc Res. 1999;58(3):312-28.

109. Rhea EM, Salameh TS, Logsdon AF, Hanson AJ, Erickson MA, Banks WA Blood-Brain Barriers in Obesity. AAPS Journal. 2017;19(4):921-30.

110. Deane R, Segal MB. The transport of sugars across the perfused choroid plexus of the sheep. J Physiol. 1985;362(1):245-60.

111. Deane R, Zheng W, Zlokovic BV. Brain capillary endothelium and choroid plexus epithelium regulate transport of transferrin-bound and free iron into the rat brain. J Neurochem. 2004;88(4):813-20.

112. Mw B. The structure and function of the blood-brain barrier. Fed Proc 1984;43(2):186-90.

113. Zheng W, Deane R, Redzic Z, Preston JE, Segal MB. Transport of L-[125I] thyroxine by in situ perfused ovine choroid plexus: inhibition by lead exposure. J Toxicol Environ Health Part A. 2003;66(5):435-51.

114. Deane R, LaRue B, Sagare AP, Castellino FJ, Zhong Z, Zlokovic BV. Endothelial protein $C$ receptor-assisted transport of activated protein $C$ across the mouse blood-brain barrier. J Cerebral Blood Flow Metabol. 2009;29(1):25-33.

115. Brightman MW, Reese TS. Junctions between intimately apposed cell membranes in the vertebrate brain. J Cell Biol. 1969;40(3):648-77.

116. Reese TS, Karnovsky MJ. Fine structural localization of a blood-brain barrier to exogenous peroxidase. J Cell Biol. 1967;34(1):207-17.

117. Abbott NJ, Patabendige AAK, Dolman DEM, Yusof SR, Begley DJ. Structure and function of the blood-brain barrier. Neurobiol Dis. 2010:37(1):13-25.

118. Jiménez AJ, Domínguez-Pinos MD, Guerra MM, Fernández-Llebrez P, Pérez-Fígares JM. Structure and function of the ependymal barrier and diseases associated with ependyma disruption. Tissue Barriers. 2014:2:1-14.

119. Nelson DJ, Wright EM. The distribution, activity, and function of the cilia in the frog brain. J Physiol. 1974;243(1):63-78.

120. Bouillé C, Mesnil M, Barriere H, Gabrion J. Gap junctional intercellular communication between cultured ependymal cells, revealed by lucifer yellow CH transfer and freeze-fracture. Glia. 1991;4(1):25-36.

121. Brightman MW, Palay SL. The, fine structure, of ependyma, in the brain of the rat. J Cell Biol. 1963;19(2):415-39.

122. Söhl G, Odermatt B, Maxeiner S, Degen J, Willecke K. New insights into the expression and function of neural connexins with transgenic mouse mutants. In: Brain Research Reviews. Brain Res Brain Res Rev; 2004. p. 245-59.

123. Yamamoto T, Kardami E, Nagy Jl. Basic fibroblast growth factor in rat brain: localization to glial gap junctions correlates with connexin43 distribution. Brain Res. 1991;554(1-2):336-43.

124. Banizs B, Pike MM, Millican CL, Ferguson WB, Komlosi P, Sheetz J, et al. Dysfunctional cilia lead to altered ependyma and choroid plexus function, and result in the formation of hydrocephalus. Development 2005;132(23):5329-39.

125. Abbott NJ, Friedman A. Overview and introduction: the blood-brain barrier in health and disease. Epilepsia. 2012;53(6):1-6.

126. Liddelow SA. Development of the choroid plexus and blood-CSF barrier. Vol. 9, Frontiers in Neuroscience. Frontiers Media S.A.; 2015.

127. Davson $H$, Segal MB. Effect of cerebrospinal fluid on volume of distribution of extracellular markers. Vol. 92, Brain. 1969. 
128. Davson H, Segal MB. The effects of some inhibitors and accelerators of sodium transport on the turnover of $22 \mathrm{Na}$ in the cerebrospinal fluid and the brain. J Physiol. 1970;209(1):131-53.

129. Davson $\mathrm{H}$, Hollingsworth $\mathrm{G}$, Segal MB. The mechanism of drainage of the cerebrospinal fluid. Vol. 93, Brain. 1970.

130. Davson H, Segal MB, Malcolm B. Physiology of the CSF and blood-brain barriers. CRC Press; 1996, p. 822.

131. Johanson CE, Duncan JA, Klinge PM, Brinker T, Stopa EG, Silverberg GD. Multiplicity of cerebrospinal fluid functions: new challenges in health and disease. Cerebrospinal Fluid Res. 2008;5:32.

132. Pollay M. The function and structure of the cerebrospinal fluid outflow system. Cerebrospinal Fluid Res. 2010;7:20.

133. Jones HC, Keep RF, Drewes LR. CNS fluid and solute movement: Physiology, modelling and imaging. Fluids and Barriers of the CNS. BioMed Central Ltd.; 2020, p. 12. https://doi.org/10.1186/s12987-020-0174-1

134. Fame RM, Lehtinen MK. Emergence and developmental roles of the cerebrospinal fluid system. Developmental Cell. Cell Press; 2020. p. 261-75.

135. Bradbury MW, Westrop RJ. Factors influencing exit of substances from cerebrospinal fluid into deep cervical lymph of the rabbit. J Physiol. 1983;339(1):519-34

136. Johnston M, Zakharov A, Papaiconomou C, Salmasi G, Armstrong D. Evidence of connections between cerebrospinal fluid and nasal lymphatic vessels in humans, non-human primates and other mammalian species. Cerebrospinal Fluid Res. 2004;1(1):1-3.

137. Kida S, Pantazis A, Weller RO. CSF drains directly from the subarachnoid space into nasal lymphatics in the rat. Anatomy, histology and immunological significance. Neuropathol Appl Neurobiol. 1993;19(6):480-8.

138. Brady M, Rahman A, Combs A, Venkatraman C, Kasper RT, McQuaid C, et al. Cerebrospinal fluid drainage kinetics across the cribriform plate are reduced with aging. Fluids Barriers CNS. 2020;17(1):71.

139. Davson H, Welch K, Segal MB. The physiology and pathophysiology of the cerebrospinal fluid. Ann Neurol. 1987;24(1):106-106.

140. Kim J, Alejandro BI, Hetman M, Hattab IDEM, Joiner J, Schroten H, et al. Zika virus infects pericytes in the choroid plexus and enters the central nervous system through the blood-cerebrospinal fluid barrier. PLoS Pathog. 2020. https://doi.org/10.1371/journal.ppat.1008204.

141. O'BA, Id H, Morris-Love J, Gee Id G V, Haley Id SA, Atwood Id WJ. JC Virus infected choroid plexus epithelial cells produce extracellular vesicles that infect glial cells independently of the virus attachment receptor. 2020. https://doi.org/10.1371/journal.ppat.1008371

142. Falangola MF, Hanly A, Galvao-Castro B, Petito CK. HIV infection of human choroid plexus: a possible mechanism of viral entry into the CNS. J Neuropathol Exp Neurol. 1995;54(4):497-503.

143. Bragg DC, Childers TA, Tompkins MB, Tompkins WA, Meeker RB. Infection of the choroid plexus by feline immunodeeciency virus. J Neurovirol. 2002;8:211-24.

144. Pellegrini L, Albecka A, Mallery DL, Kellner MJ, Paul D, Carter AP, et al. SARS-CoV-2 infects the brain choroid plexus and disrupts the blood-csf barrier in human brain organoids. Cell Stem Cell. 2020;27(6):951-961.e5. https://doi.org/10.1016/j.stem.2020.10.001.

145. Finsterer, Josef Stollberger C. Update on the neurology of COVID-19. 2020;0-3.

146. Moriguchi T, Harii N, Goto J, Harada D, Sugawara H, Takamino J, et al. A first case of meningitis/encephalitis associated with SARS-Coronavirus-2. Int J Infect Dis. 2020;1 (94):55-8.

147. Huang YH, Jiang D, Huang JT. SARS-CoV-2 detected in cerebrospinal fluid by PCR in a case of COVID-19 encephalitis. Brain Behav Immunity. 2020;87:149.

148. Garg R. Spectrum of neurological manifestations in covid-19: a review. Neurol India. 2020;68(3):560

149. Engelhardt B, Vajkoczy P, Weller RO. The movers and shapers in immune privilege of the CNS. Berlin: Nature Publishing Group; 2017.

150. Bajénoff M, Germain RN. Seeing is believing: a focus on the contribution of microscopic imaging to our understanding of immune system function. Eur J Immunol. 2007;37(SUPPL. 1):S18-33.

151. Bousso P, Bhakta NR, Lewis RS, Robey E. Dynamics of thymocytestromal cell interactions visualized by two-photon microscopy. Science. 2002;296(5574):1876-80.

152. Wilson $\mathrm{EH}$, Weninger $\mathrm{W}$, Hunter CA. Trafficking of immune cells in the central nervous system. J Clin Invest. 2010;120:1368-79.
153. Hoeve MA, Nash AA, Jackson D, Randall RE, Dransfield I. Influenza virus A infection of human monocyte and macrophage subpopulations reveals increased susceptibility associated with cell differentiation. PLoS ONE. 2012;7(1):29443

154. Michlmayr D, Andrade P, Gonzalez K, Balmaseda A, Harris E. CD14+CD16+ monocytes are the main target of Zika virus infection in peripheral blood mononuclear cells in a paediatric study in Nicaragua. Nat Microbiol. 2017;2(11):1462-70. https://doi.org/10.1038/ s41564-017-0035-0.

155. Nikitina E, Larionova I, Choinzonov E, Kzhyshkowska J. Molecular sciences monocytes and macrophages as viral targets and reservoirs. 2018. www.mdpi.com/journal/ijms

156. Martinez FO, Combes TW, Orsenigo F, Gordon S. Monocyte activation in systemic Covid-19 infection: assay and rationale. EBioMedicine. 2020;59:102964. https://doi.org/10.1016/j.ebiom.2020.102964.

157. Mao L, Wang M, Chen S, He Q, Chang J, Hong C, et al. Neurological Manifestations of Hospitalized Patients with COVID-19 in Wuhan, China: a retrospective case series study. medRxiv. 2020;

158. Li Y, Li M, Wang M, Zhou Y, Chang J, Xian Y, et al. Acute cerebrovascular disease following COVID-19: a single center, retrospective, observational study. Stroke Vasc Neurol. 2020;5(3):279-84.

159. Zach H, Dirkx MF, Pasman JW, Bloem BR, Helmich RC. Cognitive stress reduces the effect of levodopa on Parkinson's resting tremor. CNS Neurosci Ther. 2017:23(3):209-15.

160. Ehgoetz Martens KA, Hall JM, Georgiades MJ, Gilat M, Walton CC, Matar $\mathrm{E}$, et al. The functional network signature of heterogeneity in freezing of gait. Brain. 2018;141(4):1145-60.

161. Macht M, Kaussner Y, Möller JC, Stiasny-Kolster K, Eggert KM, Krüger HP, et al. Predictors of freezing in Parkinson's disease: a survey of 6,620 patients. Mov Disord. 2007;22(7):953-6.

162. Zach H, Dirkx M, Pasman JW, Bloem BR, Helmich RC. The patient's perspective: the effect of levodopa on Parkinson symptoms. Parkinsonism Relat Disord. 2017;1(35):48-54.

163. Castelnuovo G, Zhu X, Francisco R, Pedro M, Delvecchio E, Pedro Espada $J$, et al. Psychological symptoms and behavioral changes in children and adolescents during the early phase of COVID-19 quarantine in three European Countries. Frontiers in Psychiatry | www.frontiersin.org [Internet]. 2020;11:570164. www.frontiersin.org

164. Knell G, Robertson MC, Dooley EE, Burford K, Mendez KS. Health behavior changes during covid-19 pandemic and subsequent "stay-at-home" orders. Int J Environ Res Public Health. 2020;17(17):1-16.

165. COVIDView Weekly Summary |CDC [Internet]. CDC. 2020. p. 1. https:// www.cdc.gov/coronavirus/2019-ncov/covid-data/covidview/index. html. Accessed 4 May 2020.

166. Morfopoulou S, Brown JR, Davies EG, Anderson G, Virasami A, Qasim W, et al. Human coronavirus OC43 associated with fatal encephalitis. N Engl J Med. 2016:375(5):497-8.

167. Yeh EA, Collins A, Cohen ME, Duffner PK, Faden H. Detection of coronavirus in the central nervous system of a child with acute disseminated encephalomyelitis. Pediatrics. 2004;113(1 Pt 1):e73-6.

168. Merkler AE, Parikh NS, Mir S, Gupta A, Kamel H, Lin E, et al. Risk of ischemic stroke in patients with coronavirus disease 2019 (COVID-19) vs patients with influenza. JAMA Neurol. 2020;77(11):1366-72.

169. Ellul MA, Benjamin L, Singh B, Lant S, Michael BD, Easton A, et al. Neurological associations of COVID-19. Lancet Neurol. 2020;19:767-83.

170. Oxley TJ, Mocco J, Majidi S, Kellner CP, Shoirah H, Singh IP, et al. Largevessel stroke as a presenting feature of covid-19 in the young. N Engl J Med. 2020;382(20):e60.

171. Belani P, Schefflein J, Kihira S, Rigney B, Delman BN, Mahmoudi K, et al. COVID-19 Is an independent risk factor for acute ischemic stroke. Am J Neuroradiol. 2020;41(8):1361-4.

172. Wang A, Mandigo GK, Yim PD, Meyers PM, Lavine SD. Stroke and mechanical thrombectomy in patients with COVID-19: technical observations and patient characteristics. J Neurolntervent Surg. 2020;12(7):648-53.

173. Majidi S, Fif JT, Ladner TR, Lara-Reyna J, Yaeger KA, Yim B, et al. Emergent large vessel occlusion stroke during New York City's COVID-19 outbreak: clinical characteristics and paraclinical findings. Stroke. 2020;51(9):2656-63. 
174. Yaghi S, Ishida K, Torres J, Mac Grory B, Raz E, Humbert K, et al. SARS-CoV-2 and stroke in a New York healthcare system. Stroke. 2020;51(7):2002-11.

175. Varga Z, Flammer AJ, Steiger P, Haberecker M, Andermatt R, Zinkernagel AS, et al. Endothelial cell infection and endotheliitis in COVID19. The Lancet. 2020;395(10234):1417-8.

176. Rapkiewicz AV, Mai X, Carsons SE, Pittaluga S, Kleiner DE, Berger JS, et al. Megakaryocytes and platelet-fibrin thrombi characterize multiorgan thrombosis at autopsy in COVID-19: a case series. EClinicalMedicine. 2020;24:100434.

177. Goshua G, Pine AB, Meizlish ML, Chang CH, Zhang H, Bahel P, et al. Endotheliopathy in COVID-19-associated coagulopathy: evidence from a single-centre, cross-sectional study. Lancet Haematol. 2020;7(8):e575-82.

178. Lau KK, Yu WC, Chu CM, Lau ST, Sheng B, Yuen KY. Possible central nervous system infection by SARS coronavirus. Emerg Infect Dis. 2004;10(2):342-4.

179. Xu J, Zhong S, Liu J, Li L, Li Y, Wu X, et al. Detection of severe acute respiratory syndrome coronavirus in the brain: potential role of the chemokine mig in pathogenesis. Clin Infect Dis. 2005;41(8):1089-96.

180. Kim JE, Heo JH, Kim HO, Song SH, Park SS, Park TH, et al. Neurological complications during treatment of middle east respiratory syndrome. J Clin Neurol. 2017;13(3):227-33.

181. McCray PB, Pewe L, Wohlford-Lenane C, Hickey M, Manzel L, Shi L, et al. Lethal infection of K18-hACE2 mice infected with severe acute respiratory syndrome coronavirus. J Virol. 2007;81(2):813-21.

182. St-Jean JR, Jacomy H, Desforges M, Vabret A, Freymuth F, Talbot PJ. Human respiratory coronavirus OC43: genetic stability and neuroinvasion. J Virol. 2004;78(16):8824-34

183. Netland J, Meyerholz DK, Moore S, Cassell M, Perlman S. Severe acute respiratory syndrome coronavirus infection causes neuronal death in the absence of encephalitis in mice transgenic for human ACE2. J Virol. 2008;82(15):7264-75.

184. Li K, Wohlford-Lenane C, Perlman S, Zhao J, Jewell AK, Reznikov LR, et al. Middle east respiratory syndrome coronavirus causes multiple organ damage and lethal disease in mice transgenic for human dipeptidyl peptidase 4. J Infect Dis. 2015;212(11):712-22.

185. Desforges M, Le Coupanec A, Dubeau P, Bourgouin A, Lajoie L, Dubé $M$, et al. Human coronaviruses and other respiratory viruses: underestimated opportunistic pathogens of the central nervous system? Viruses. 2019;12:24.

186. Pellegrini $L$, Albecka A, Mallery DL, Kellner MJ, Paul D, Carter AP, et al. SARS-CoV-2 infects brain choroid plexus and disrupts the blood-CSFbarrier. bioRxiv. 2020 Aug 21;2020.08.20.259937.

187. Giri R, Shen Y, Stins M, Du YS, Schmidt AM, Stern D, et al. $\beta$-Amyloidinduced migration of monocytes across human brain endothelial cells involves RAGE and PECAM-1. Am J Physiol Cell Physiol. 2000;279(6):48-56.

188. Rietdijk CD, Perez-Pardo P, Garssen J, van Wezel RJA, Kraneveld AD Exploring Braak's hypothesis of parkinson's disease. Front Neurol. 2017;8(FEB):1.

189. Butowt R, Bilinska K. SARS-CoV-2: olfaction, brain infection, and the urgent need for clinical samples allowing earlier virus detection. ACS Chem Neurosci. 2020;11:1200-3.

190. Audrit KJ, Delventhal L, Aydin Ö, Nassenstein C. The nervous system of airways and its remodeling in inflammatory lung diseases. Cell Tissue Res. 2017;367:571-90.

191. Driessen AK, Farrell MJ, Mazzone SB, McGovern AE. Multiple neural circuits mediating airway sensations: recent advances in the neurobiology of the urge-to-cough. Respir Physiol Neurobiol. 2016;1 (226):115-20.

192. Sorby-Adams AJ, Marcoionni AM, Dempsey ER, Woenig JA, Turner RJ. The role of neurogenic inflammation in blood-brain barrier disruption and development of cerebral oedema following acute central nervous system (CNS) injury. Int J Mol Sci. 2017;18:1788.

193. von Weyhern CH, Kaufmann I, Neff F, Kremer M. Early evidence of pronounced brain involvement in fatal COVID-19 outcomes. Lancet. 2020;395:e109.

194. Politi LS, Salsano E, Grimaldi M. Magnetic resonance imaging alteration of the brain in a patient with coronavirus disease 2019 (COVID-19) and anosmia. JAMA Neurol. 2020;77:1028-9.
195. Baig AM, Khaleeq A, Ali U, Syeda H. Evidence of the COVID-19 virus targeting the CNS: tissue distribution, host-virus interaction, and proposed neurotropic mechanisms. ACS Chem Neurosci. 2020;11:995.

196. Meinhardt J, Radke J, Dittmayer C, Franz J, Thomas C, Mothes R, et al. Olfactory transmucosal SARS-CoV-2 invasion as a port of central nervous system entry in individuals with COVID-19. Nat Neurosci. https:// doi.org/10.1038/s41593-020-00758-5

197. CK B, HT H, A B-T, WR B, T H, CK, et al. Infectability of human BrainSphere neurons suggests neurotropism of SARS-CoV-2. ALTEX [Internet]. 2020;37(4). https://pubmed.ncbi.n/m.nih.gov/32591839/

198. Ramani A, Müller L, Ostermann PN, Gabriel E, Abida-Islam P, MüllerSchiffmann A, et al. SARS-CoV-2 targets neurons of 3D human brain organoids. EMBO J. 2020;39(20):e106230.

199. Song E, Zhang C, Israelow B, Lu-Culligan A, Prado AV, Skriabine S, et al. Neuroinvasion of SARS-CoV-2 in human and mouse brain. J Exp Med. 2021;218(3):e20202135.

200. Murray RS, Cai GY, Hoel K, Zhang JY, Soike KF, Cabirac GF. Coronavirus infects and causes demyelination in primate central nervous system. Virology. 1992;188(1):274-84.

201. De Santis G. SARS-CoV-2: a new virus but a familiar inflammation brain pattern. Brain Behav Immunity. 2020;347(xxxx):1-2.

202. Butler N, Pewe L, Trandem K, Perlman S. Murine encephalitis caused by HCoV-OC43, a human coronavirus with broad species specificity, is partly immune-mediated. Virology. 2006;347(2):410-21.

203. Hachem M. SARS-CoV-2 journey to the brain with a focus on potential role of docosahexaenoic acid bioactive lipid mediators. Biochimie. 2021;184:95-103.

204. Chen G, Wu D, Guo W, Cao Y, Huang D, Wang H, et al. Clinical and immunological features of severe and moderate coronavirus disease 2019. J Clin Invest. 2020;130(5):2620-9.

205. L C, HG L, W L, J L, K L, J S, et al. [Analysis of clinical features of 29 patients with 2019 novel coronavirus pneumonia]. Zhonghua jie he he hu xi za zhi = Zhonghua jiehe he huxi zazhi = Chinese journal of tuberculosis and respiratory diseases. 2020;43(0).

206. Qin C, Zhou L, Hu Z, Zhang S, Yang S, Tao Y, et al. Dysregulation of immune response in patients with coronavirus 2019 (COVID-19) in Wuhan. China Clin Infect Dis. 2020;71(15):762-8.

207. Tan M, Liu Y, Zhou R, Deng X, Li F, Liang K, et al. Immunopathological characteristics of coronavirus disease 2019 cases in Guangzhou. China Immunol. 2020;160(3):261-8.

208. Huang C, Wang Y, Li X, Ren L, Zhao J, Hu Y, et al. Clinical features of patients infected with 2019 novel coronavirus in Wuhan China. Lancet. 2020;395(10223):497-506.

209. Liu F, Li L, Da XuM, Wu J, Luo D, Zhu YS, et al. Prognostic value of interleukin-6, C-reactive protein, and procalcitonin in patients with COVID-19. J Clin Virol. 2020;127:104370.

210. Tisoncik JR, Korth MJ, Simmons CP, Farrar J, Martin TR, Katze MG. Into the eye of the cytokine storm. Microbiol Mol Biol Rev. 2012;76(1):16-32.

211. Wang D, Hu B, Hu C, Zhu F, Liu X, Zhang J, et al. Clinical characteristics of 138 hospitalized patients with 2019 novel coronavirus-infected pneumonia in Wuhan, China. JAMA. 2020;323(11):1061-9.

212. Guan W, Ni Z, Hu Y, Liang W, Ou C, He J, et al. Clinical characteristics of coronavirus disease 2019 in China. N Engl J Med. 2020;382(18):1708-20.

213. Channappanavar R, Perlman S. Pathogenic human coronavirus infections: causes and consequences of cytokine storm and immunopathology. Seminars Immunopathol. 2017;39:529-39.

214. Xu Z, Shi L, Wang Y, Zhang J, Huang L, Zhang C, et al. Pathological findings of COVID-19 associated with acute respiratory distress syndrome. Lancet Respir Med. 2020;8(4):420-2.

215. Chen J, Subbarao K. The immunobiology of SARS. Annu Rev Immunol. 2007;45:443-72.

216. Cameron MJ, Ran L, Xu L, Danesh A, Bermejo-Martin JF, Cameron CM, et al. Interferon-mediated immunopathological events are associated with atypical innate and adaptive immune responses in patients with severe acute respiratory syndrome. J Virol. 2007;81(16):8692-706.

217. Huang KJ, Su IJ, Theron M, Wu YC, Lai SK, Liu CC, et al. An interferon- $\gamma$ related cytokine storm in SARS patients. J Med Virol. 2005;75(2):185-94.

218. Gu J, Gong E, Zhang B, Zheng J, Gao Z, Zhong Y, et al. Multiple organ infection and the pathogenesis of SARS. J Exp Med. 2005;202(3):415-24. 
219. LiT, Qiu Z, Zhang L, Han Y, He W, Liu Z, et al. Significant changes of peripheral $T$ lymphocyte subsets in patients with severe acute respiratory syndrome. J Infect Dis. 2004;189(4):648-51.

220. Menachery VD, Eisfeld AJ, Schäfer A, Josset L, Sims AC, Proll S, et al. Pathogenic influenza viruses and coronaviruses utilize similar and contrasting approaches to control interferon-stimulated gene responses. MBio. 2014;5(3):e01174-e1214.

221. Lau SKP, Lau CCY, Chan KH, Li CPY, Chen H, Jin DY, et al. Delayed induCtion of proinflammatory cytokines and suppression of innate antiviral response by the novel Middle East respiratory syndrome coronavirus: implications for pathogenesis and treatment. J Gen Virol 2013;94(PART 12):2679-90.

222. Yen Y-T, Liao F, Hsiao C-H, Kao C-L, Chen Y-C, Wu-Hsieh BA. Modeling the early events of severe acute respiratory syndrome coronavirus infection in vitro. J Virol. 2006;80(6):2684-93.

223. Tynell J, Westenius V, Rönkkö E, Munster VJ, Melén K, Österlund P, et al. Middle east respiratory syndrome coronavirus shows poor replication but significant induction of antiviral responses in human monocyte-derived macrophages and dendritic cells. J Gen Virol. 2016;97(2):344-55.

224. Zhou J, Chu H, Li C, Wong BHY, Cheng ZS, Poon VKM, et al. Active replication of middle east respiratory syndrome coronavirus and aberrant induction of inflammatory cytokines and chemokines in human macrophages: Implications for pathogenesis. J Infect Dis. 2014;209(9):1331-42.

225. Law HKW, Chung YC, Hoi YN, Sin FS, Yuk OC, Luk W, et al. Chemokine up-regulation in SARS-coronavirus-infected, monocyte-derived human dendritic cells. Blood. 2005;106(7):2366-74.

226. Cheung CY, Poon LLM, Ng IHY, Luk W, Sia S-F, Wu MHS, et al. Cytokine responses in severe acute respiratory syndrome coronavirus-infected macrophages in vitro: possible relevance to pathogenesis. J Virol. 2005;79(12):7819-26.

227. Erickson MA, Banks WA. Neuroimmune axes of the blood-brain barriers and blood-brain interfaces: bases for physiological regulation, disease states, and pharmacological interventions. Pharmacol Rev. 2018;70(2):278-314. https://doi.org/10.1124/pr.117.014647.

228. de Vries HE, Blom-Roosemalen MCM, van Oosten M, de Boer AG, van Berkel TJC, Breimer DD, et al. The influence of cytokines on the integrity of the blood-brain barrier in vitro. J Neuroimmunol. 1996;64(1):37-43.

229. Banks WA. The blood-brain barrier in neuroimmunology: Tales of separation and assimilation. Brain Behav Immunity. 2015;44:1-8.

230. Banks W. Blood-Brain Barrier transport of cytokines: a mechanism for neuropathology. Curr Pharma Design. 2005;11(8):973-84.

231. COVIDView: May 9th a weekly surveillance summary of U.S. COVID-19 activity | CDC [Internet]. 2020. https://www.cdc.gov/coronavirus/2019ncov/covid-data/covidview/index.html. Accessed 20 May 2020.

232. Buttler L, Jordão MT, Fragas MG, Ruggeri A, Ceroni A, Michelini LC. Maintenance of blood-brain barrier integrity in hypertension: a novel benefit of exercise training for autonomic control. Front Physiol. 2017;8(DEC):1-14.

233. Nalbandian A, Sehgal K, Gupta A, Madhavan MV, McGroder C, Stevens JS, et al. Post-acute COVID-19 syndrome. Nat Med. 2021. https://doi. org/10.1038/s41591-021-01283-z.

234. Bell RD, Winkler EA, Sagare AP, Singh I, LaRue B, Deane R, et al. Pericytes control key neurovascular functions and neuronal phenotype in the adult brain and during brain aging. Neuron. 2010;68(3):409-27.

235. Rosenberg GA, Cunningham LA, Wallace J, Alexander S, Estrada EY, Grossetete M, et al. Immunohistochemistry of matrix metalloproteinases in reperfusion injury to rat brain: activation of MMP-9 linked to stromelysin-1 and microglia in cell cultures. Brain Res. 2001;893(1-2):104-12.

236. Wei M, Li H, Shang Y, Zhou Z, Zhang J. Increased CD147 (EMMPRIN) expression in the rat brain following traumatic brain injury. Brain Res. 2014;17(1585):150-8.

237. Pan P, Zhao H, Zhang X, Li Q, Qu J, Zuo S, et al. Cyclophilin a signaling induces pericyte-associated blood-brain barrier disruption after subarachnoid hemorrhage. J Neuroinflammation. 2020;17(1):16.

238. Hawkins BT, Lundeen TF, Norwood KM, Brooks HL, Egleton RD Increased blood-brain barrier permeability and altered tight junctions in experimental diabetes in the rat: contribution of hyperglycaemia and matrix metalloproteinases. Diabetologia. 2007;50(1):202-11.
239. Kress BT, lliff JJ, Xia M, Wang M, Wei Bs HS, Zeppenfeld D, et al. Impairment of paravascular clearance pathways in the aging brain. Ann Neurol. 2014;76(6):845-61.

240. Erickson MA, Banks WA. Age-associated changes in the immune system and blood-brain barrier functions. Int J Mol Sci. 2019;20(7):1632.

241. Singh I, Sagare AP, Coma M, Perlmutter D, Gelein R, Bell RD, et al. Low levels of copper disrupt brain amyloid- $\beta$ homeostasis by altering its production and clearance. Proc Natl Acad Sci USA. 2013;110(36):14771-6.

242. Cirrito JR, Deane R, Fagan AM, Spinner ML, Parsadanian M, Finn MB, et al. P-glycoprotein deficiency at the blood-brain barrier increases amyloid- $\beta$ deposition in an Alzheimer disease mouse model. J Clin Investig. 2005;115(11):3285-90.

243. Yamazaki Y, Kanekiyo T. Blood-brain barrier dysfunction and the pathogenesis of alzheimer's disease. Int J Mol Sci. 2017;18(9):1965.

244. Beck J, Horikawa I, Harris C. Cellular senescence: mechanisms, morphology, and mouse models. Vet Pathol. 2020;57:747-57.

245. Banks WA. Peptides and the blood brain barrier. Peptides. 2015;72(3):16-9.

246. Luo XG, Ding JQ, Di CS. Microglia in the aging brain: Relevance to neurodegeneration. Mol Neurodegener. 2010;5:12.

247. Montagne A, Zhao Z, Zlokovic B V. Alzheimer's disease: a matter of blood-brain barrier dysfunction? J Exp Med 2017;jem.20171406.

248. Patching SG. Glucose Transporters at the blood-brain barrier: function, regulation and gateways for drug delivery. Mol Neurobiol. 2017;54(2):1046-77.

249. Qosa H, Abuasal BS, Romero IA, Weksler B, Couraud P-O, Keller JN, et al. Differences in amyloid- $\beta$ clearance across mouse and human blood-brain barrier models: kinetic analysis and mechanistic modeling. Neuropharmacology. 2014;79:668-78.

250. Deane R, Sagare A, Zlokovic B. The role of the cell surface LRP and soluble LRP in blood-brain barrier A $\beta$ clearance in Alzheimer's Disease. Curr Pharm Des. 2008;14(16):1601.

251. FastStats-Overweight Prevalence [Internet]. 2020. https://www.cdc. gov/nchs/fastats/obesity-overweight.htm. Accessed 24 May 2020.

252. McLean FH, Campbell FM, Langston RF, Sergi D, Resch C, Grant C, et al. A high-fat diet induces rapid changes in the mouse hypothalamic proteome. Nutr Metab. 2019;16(1):26.

253. Baufeld C, Osterloh A, Prokop S, Miller KR, Heppner FL. High-fat dietinduced brain region-specific phenotypic spectrum of CNS resident microglia. Acta Neuropathol. 2016;132(3):361-75.

254. Kanoski SE, Zhang Y, Zheng W, Davidson TL. The effects of a highenergy diet on hippocampal function and blood-brain barrier integrity in the rat. J Alzheimer's Dis. 2010;21(1):207-19.

255. Thaler JP, Guyenet SJ, Dorfman MD, Wisse BE, Schwartz MW. Hypothalamic inflammation: marker or mechanism of obesity pathogenesis? Diabetes. 2013:62:2629-34.

256. Diabetes Statistics report 2020 [Internet]. 2020. https://www.diabetesre search.org/file/national-diabetes-statistics-report-2020.pdf. Accessed 11 May 2020

257. Bogush $M$, Heldt NA, Persidsky Y. Blood brain barrier injury in diabetes : unrecognized effects on brain and cognition. J Neuroimmune Pharmacol. 2017;12:593-601.

258. Gray SM, Barrett EJ. The blood-brain barrier in Diabetes Mellitus. Type 2 Diabetes and Dementia. Elsevier Inc.; 2018, p. 211-29.

259. Hadi HA, Al-Suwaidi J. Endothelial dysfunction in diabetes mellitus. Vasc Health Risk Manage. 2007;3(6):853.

260. Setiadi A, Korim WS, Elsaafien K, Yao ST. The role of the blood-brain barrier in hypertension. Exp Physiol. 2018;103(3):337-42.

261. Dinner S, Borkowski J, Stump-Guthier C, Ishikawa H, Tenenbaum T, Schroten $\mathrm{H}$, et al. A choroid plexus epithelial cell-based model of the human blood-cerebrospinal fluid barrier to study bacterial infection from the basolateral side. J Vis Exp. 2016;2016(111):54061.

262. Kläs J, Wolburg H, Terasaki T, Fricker G, Reichel V. Characterization of immortalized choroid plexus epithelial cell lines for studies of transport processes across the blood-cerebrospinal fluid barrier [Internet]. 2010. http://www.cerebrospinalfluidresearch.com/content/7/1/11

263. Kirby T. New variant of SARS-CoV-2 in UK causes surge of COVID-19. Lancet Respir Med. 2021;9(2):e20.

264. Kemp SA, Datir RP, Collier DA, Ferreira IATM, Carabelli A, Harvey W, et al. Recurrent emergence and transmission of a SARS-CoV-2 Spike deletion 
$\Delta$ H69/N70 [Internet]. bioRxiv. bioRxiv; 2020, p. 2020.12.14.422555. https://doi.org/10.1101/2020.12.14.422555. Accessed 7 Feb 2021.

265. McCarthy KR, Rennick LJ, Nambulli S, Robinson-McCarthy LR, Bain WG, Haidar G, et al. Natural deletions in the SARS-CoV-2 spike glycoprotein drive antibody escape [Internet]. bioRxiv. bioRxiv; 2020, p. 2020.11.19.389916. https://doi.org/10.1101/2020.11.19.389916. Accessed 7 Feb 2021.

266. Ecdc. Suggested citation: European Centre for Disease Prevention and Control. Rapid increase of a SARS-CoV-2 variant with multiple spike protein mutations observed in the Rapid increase of a SARS-CoV-2 variant with multiple spike protein mutations observed in the United Kingdom [Internet]. 2020. http://covid19-country-overviews.ecdc.europa.eu/\# 34_United_Kingdom. Accessed 7 Feb 2021.

267. Health England P. Investigation of novel SARS-CoV-2 variant: variant of concern 202012/01. 2021.

268. NERVTAG. NERVTAG Note on B.1.1.7 Severity | alliance for pandemic preparedness [Internet]. 2021. https://depts.washington.edu/pande micalliance/2021/01/25/nervtag-note-on-b-1-1-7-severity/. Accessed 7 Feb 2021.

269. Emary KRW, GolubchikT, Aley PK, Ariani C V., Angus BJ, Bibi S, et al. Efficacy of ChAdOx1 nCoV-19\&nbsp;(AZD1222)\&nbsp;Vaccine Against SARS-CoV-2 VOC\&nbsp;202012/01\&nbsp;(B.1.1.7). SSRN Electronic Journal [Internet]. 2021. https://www.ssrn.com/abstract=3779160. Accessed 7 Feb 2021.
270. Carl A.B. Pearson*, Timothy W Russell, Nicholas Davies, Adam J Kucharski, CMMID COVID-19 working group WJE\& RMEggo. Estimates of severity and transmissibility of novel SARS-CoV-2 variant 501Y.V2 in South Africa | CMMID Repository [Internet]. 2021. https://cmmid.github. io/topics/covid19/sa-novel-variant.html. Accessed 7 Feb 2021.

271. Wu K, Werner AP, Moliva Jl, Koch M, Choi A, Stewart-Jones GBE, et al. mRNA-1273 vaccine induces neutralizing antibodies against spike mutants from global SARS-CoV-2 variants. bioRxiv: the preprint server for biology [Internet]. 2021 Jan 25;2021.01.25.427948. Available from: http://www.ncbi.nlm.nih.gov/pubmed/33501442. Accessed 7 Feb 2021.

272. Moderna COVID-19 Vaccine retains neutralizing activity against emerging variants first identified in the U.K. and the Republic of South Africa | Moderna, Inc. [Internet]. 2021. https://investors.modernatx.com/newsreleases/news-release-details/moderna-covid-19-vaccine-retains-neutr alizing-activity-against. Accessed 7 Feb 2021.

\section{Publisher's Note}

Springer Nature remains neutral with regard to jurisdictional claims in published maps and institutional affiliations.
Ready to submit your research? Choose BMC and benefit from:

- fast, convenient online submission

- thorough peer review by experienced researchers in your field

- rapid publication on acceptance

- support for research data, including large and complex data types

- gold Open Access which fosters wider collaboration and increased citations

- maximum visibility for your research: over $100 \mathrm{M}$ website views per year

At BMC, research is always in progress.

Learn more biomedcentral.com/submissions 